\title{
Are spatial variations in the diets of hydrothermal fauna linked to local environmental conditions?
}

\author{
F. De Busserolles ${ }^{a}$, J. Sarrazin ${ }^{a}{ }^{*}$, O. Gauthier ${ }^{a}$, Y. Gélinas ${ }^{b}$, M.C. Fabri ${ }^{a}$, P.M. Sarradin ${ }^{a}$ and \\ D. Desbruyères ${ }^{a}$
}

\author{
${ }^{a}$ DEEP/LEP, Ifremer, Centre de Brest, BP 70, 29280 Plouzané, France \\ b GEOTOP and Chemistry and Biochemistry Department, Concordia University, 7141 rue Sherbrooke ouest, \\ Montréal, Québec, Canada H4B 1R6
}
*: Corresponding author: J. Sarrazin, Tel.: +33 2982243 29; fax: +33 29822 47 57, email address : Jozee.Sarrazin@ifremer.fr

\begin{abstract}
:
Trophic relationships in Bathymodiolus azoricus mussel bed communities on the Tour Eiffel hydrothermal edifice (Lucky Strike) were assessed using $\delta^{13} \mathrm{C}$ and $\delta^{15} \mathrm{~N}$ signatures from 14 hydrothermal species. The nutritional basis of $B$. azoricus was also investigated with $\delta^{34} \mathrm{~S}$. Faunal samples and environmental data (temperature, $\mathrm{pH}$, total dissolved sulfide, iron and copper concentrations) were collected from 12 different locations on the edifice. Chemical conditions varied between microhabitats, and were all correlated to temperature. Carbon and nitrogen isotopic results revealed the presence of two, apparently independent, trophic groups. The first was composed of symbiont-bearing fauna (B. azoricus and their associated polychaetes Branchipolynoe seepensis), while the second enclosed heterotrophic fauna (bacterivores, detritivores, scavengers, predators). A majority of mussels displayed $\delta^{13} \mathrm{C}$ values ranging from $-27 \%$ to $-34 \%$, supporting thiotrophy as the dominant nutritional pathway at Tour Eiffel, with methanotrophy and filter feeding emerging as secondary strategies. This result was corroborated by $\delta^{34} S$ signatures. However, higher $\delta^{13} \mathrm{C}$ values in larger mussels suggested that, as they grow, B. azoricus mussels rely more heavily on their methanotrophic endosymbionts. Significant spatial variability in isotopic signatures for single faunal species was observed at the scale of the edifice for three species (B. azoricus, $B$. seepensis, Amathys lutzi), and environmental conditions explained variation in isotopic signatures for one-third of the species. This confirms the hypothesis raised by several authors on the role of hydrothermal fluids on the trophic network at small spatial scales.

We suggest that vent fluid characteristics, by influencing microbial production, are key factors in the variation of local carbon sources at vents.
\end{abstract}

Keywords: Stable isotopes; Environmental conditions; Hydrothermal springs; Food webs; Mid-Atlantic Ridge; Lucky Strike $\left(37^{\circ} 17.29^{\prime} \mathrm{N} ; 32^{\circ} 16.45^{\prime} \mathrm{W}\right)$ 
Only a small portion of photosynthetically produced carbon reaches the seafloor at depths $>2000 \mathrm{~m}$, offering limited food sources to deep-sea organisms (Suess 1980). At hydrothermal vents, microbial chemosynthesis replaces photosynthesis as the dominant source of primary production (Jannasch 1985, Karl 1995). Chemoautotrophy refers to the biosynthesis of organic carbon compounds from $\mathrm{CO}_{2}$ or other $\mathrm{C} 1$ compounds $\left(\mathrm{CH}_{4}, \mathrm{CH}_{3} \mathrm{OH}\right)$ using the energy produced through the oxidation of reduced inorganic chemicals found in high concentrations in hydrothermal fluids (Conway et al. 1994, Karl 1995).

The characterization of the food web is an essential step to understand the functioning of vent ecosystems where microorganisms represent most of the living organic carbon in the environment (Karl 1995). Sulfur and methane oxidation by oxygen are considered to be the main energy-acquisition pathways of carbon fixation in hydrothermal systems (Conway et al. 1994, Levin and Michener 2002) but, more recently, hydrogen and ferrous iron were also identified as potential electron donors (Takai et al. 2004, Zbinden et al. 2004, Schmidt et al. 2008). Microorganisms require these substrates for energy-yielding oxidation processes and for the synthesis of cellular materials (Karl 1995). Microbial food sources are used by vent invertebrates through direct consumption of free-living microorganisms (filter feeding, grazing), through different symbiotic relationships (endo- or exo-) or through a combination of the two. Free-living microbes, growing on hard surfaces or proliferating in hydrothermal fluids, represent potentially important nutritional sources. In addition, symbiotic associations appear to play a major role in the nutrition of a wide range of invertebrate taxa that include bivalves, polychaetes and crustaceans (Fisher et al. 1987, Childress and Fisher 1992, Jahnke et al. 1995, Pond et al. 1998, Bergquist et al. 2007, Halary et al. 2008). Dual symbioses involving methane- and sulfur-oxidizing bacteria occur in the gills of several species of hydrothermal and seep mussels (Duperron et al. 2006, Halary et al. 2008). In addition to the microbial compartment, particulate and dissolved organic matter (POM, DOM) from differing sources (pelagic/hydrothermal) may be used by non-symbiotic fauna. Predator, detritivore and scavenger species complete the typical hydrothermal trophic network (Tunnicliffe and Jensen 1987, Tunnicliffe 1991, Voight 2000, Sancho et al. 2005). Nonendemic benthic background fauna take advantage of the enhanced productivity found near vents and contribute to the exportation of organic carbon in the surrounding deep-sea ecosystem (Micheli et al. 2002).

Stable isotope analyses are increasingly used in the study of deep-sea chemosynthetic ecosystems. Carbon and nitrogen stable isotope signatures provide insight into the trophic structure and energy flow network of these relatively constrained communities. The carbon isotope $\left(\delta^{13} \mathrm{C}\right)$ signature is an indicator of assimilated food. It remains relatively constant between successive trophic levels depending on the tissue analyzed and its preparation (Conway et al. 1994, Lorrain et al. 2002, McCutchan et al. 2003). On the other hand, the nitrogen $\left(\delta^{15} \mathrm{~N}\right)$ isotope signature becomes more and more enriched as it passes from primary producers to primary consumers and to higher trophic levels and is considered to be a good indicator of an organism's trophic position (Minagawa and Wada 1984). Finally, the isotopic composition of sulfur in faunal tissues can help determine the ultimate basis of an organism's diet (thiotrophy or methanotrophy; Vetter and Fry 1998).

The first vent isotopic studies showed that $\delta^{13} \mathrm{C}$ of hydrothermal organisms were depleted compared to those of typical deep-sea heterotrophs, supporting the hypothesis of an autochthonous source of organic carbon (Rau and Hedges 1979, Rau 1981a, b). Jannasch et al. (1989) and Fisher et al. (1990) independently confirmed that hydrothermal vent primary producers are chemoautotrophic bacteria. Since then, numerous studies on the stable isotope composition of vent species have been conducted in vent fields around the world (Desbruyères et al. 1983, Van Dover et al. 1988, Van Dover and Fry 1989, Fisher et al. 1994, Southward et al. 1994, Pond et al. 1997a, b, 1998, Polz et al. 1998, Robinson et al. 1998, 
Rieley et al. 1999, Vereshchaka et al. 2000, Gebruk et al. 2000, Colaço et al. 2002a, Limen and Juniper 2006, Limen et al. 2007, Bergquist et al. 2007). Results of these studies show that despite the presence of a limited number of species, the hydrothermal trophic structure may be complex (Bergquist et al. 2007). Trophic specialists appear to coexist with generalists, supporting the hypothesis of resource partitioning in the vent habitat (Tsurumi and Tunnicliffe 2003, Levesque et al. 2006). High variability in the average isotopic signature values for a species may indicate the presence of a large variety of food sources (generalists), while narrow values represent specialist feeding strategies (Limen and Juniper 2006, Bergquist et al. 2007). Only a few consumers appear to specialize on known symbiontbearing fauna, limiting the perceived role of symbiosis in the vent food web and raising the question of the fate of the massive production generated by symbionts (Van Dover and Fry 1994, Bergquist et al. 2007). In addition, the clear dominance of deposit feeders, compared to filter feeders, supports the hypothesis that attached free-living microorganisms are prime players in the nutrition of the vent fauna, at least from diffuse flow habitats (Bergquist et al. 2007).

The present study focuses on the mussel beds that represent one of the dominant faunal assemblages of the Mid-Atlantic Ridge (MAR) hydrothermal ecosystem (Comtet et al. 1998, Colaço et al. 1998, Trask and Van Dover 1999, Van Dover and Trask 2000, Desbruyères et al. 2001). Bathymodiolus azoricus is the foundation species in these assemblages which may harbor over 30 associated taxa on Tour Eiffel (Sarrazin et al. in prep). The goal of this study is to examine the dietary differences of Bathymodiolus azoricus and 13 accompanying hydrothermal species by investigating carbon and nitrogen isotope ratios at 12 locations and to propose a well-defined food web structure for the mussel assemblages on the Tour Eiffel edifice. A brief investigation of sulfur isotope ratio differences among mussel assemblages from three contrasting habitats is also presented. Chemical characteristics of vent fluids are hypothesized to influence $\delta^{13} \mathrm{C}$ and $\delta^{15} \mathrm{~N}$ isotope signatures (Trask and Van Dover 1999, Gebruk et al. 2000, Colaço et al. 2002b, Robinson et al. 2003, Limen and Juniper 2006) but despite known high spatial variability of environmental conditions at vents (Sarrazin et al. 1999, Luther et al. 2001, Sarradin et al. 2009), this hypothesis has never been tested before. Therefore, results of this study provide answers to the following questions: Is there significant spatial variation in stable isotope signatures of the different species at Tour Eiffel? Does the variation in stable isotope signatures change with mussel tissue or size? Is the variation in stable isotope signatures linked with the environmental conditions experienced by the fauna?

\section{Materials and methods}

\subsection{Study site}

The region of the MAR located close to the Azores Triple Junction (ATJ) has been extensively studied over the past 15 years. Several cruises have been conducted in the area, leading to the discovery of numerous vent fields located on the south-eastern limb of the ATJ. Lucky Strike $\left(37^{\circ} 17.29^{\prime} \mathrm{N}, 32^{\circ} 16.45^{\prime} \mathrm{W}\right)$ is one of the largest known active vent fields in the world ocean. Well-defined hydrothermal edifices such as Tour Eiffel, as well as diffuse flow areas, are scattered in the vent field. They are distributed around a large lava lake at depths varying from 1650 to $1750 \mathrm{~m}$ (Fouquet et al. 1995, Desbruyères et al. 2001, Ondréas et al. in press). The composition of hydrothermal fluids varies significantly from site to site, suggesting the presence of two fluid sources (Charlou et al. 2000).

\subsection{Sampling and preservation}

The MoMARETO cruise was held in 2006 on the new French research vessel Pourquoi pas? with the remotely operated vehicle Victor 6000 (Sarrazin et al. 2006). Fauna and chemical data were collected on the $11 \mathrm{~m}$ tall Tour Eiffel sulfide edifice. To obtain a representative 
overview of the faunal assemblages, 12 locations (C1 to C12) were chosen at different depths on either side of the edifice (Fig. 1).

Chemical conditions within the 12 locations were assessed by in situ measurements and water sampling. Total dissolved iron (TdFe) and total dissolved sulfide (TdS) concentrations $\left(\mathrm{H}_{2} \mathrm{~S}+\mathrm{HS}^{-}+\mathrm{S}^{-}\right)$were measured in situ using the chemical analyser CHEMINI (Vuillemin et al. in press). Temperature was measured with an autonomous temperature probe (NKE) attached to the sampling inlets. Water samples were collected with the PEPITO sampling device (Sarradin et al. 2009). The $\mathrm{pH}$ was measured on board at $25^{\circ} \mathrm{C}$ using a combined $\mathrm{pH}$ electrode (Ingold $($ ) $)$ for sulfide-rich medium after calibration with NBS buffers $(\mathrm{pH} 4$ and 7 ) while total dissolved copper ( $\mathrm{TdCu}$ ), was measured by stripping chronopotentiometry (SCP) with a gold electrode (Riso et al. 1997). A reference temperature was taken outside the area influenced by hydrothermal fluids. All abiotic sampling and analytical procedures are described in Sarradin et al. (2009).

The fauna was semi-quantitatively sampled using Victor's suction sampler and arm grab. Once brought on board, the faunal samples were washed, sieved $(63 \mu \mathrm{m})$ and sorted. Representative individuals of the most dominant mega- and macrofaunal species were subsampled and frozen $\left(-80^{\circ} \mathrm{C}\right)$ for stable isotope analyses. The shells of the $B$. azoricus mussels selected for isotopic analyses were measured (length, width and thickness) with a caliper $( \pm 0.05 \mathrm{~mm})$. All remaining samples were fixed in $4 \%$ buffered formalin. After two days, they were transferred to $70 \%$ ethanol and, once in the laboratory, identified to the lowest possible taxonomic level using morphological characters.

\subsection{Sample preparation and stable isotope determination}

Tissue samples for analysis of stable carbon and nitrogen isotopes were collected from a total of 14 taxonomic groups. Frozen individuals of each taxon from each location were defrosted and dissected. When the number of frozen individuals was insufficient, alcoholpreserved individuals were used. Isolated muscle tissue was used for sufficiently large individuals. Tissues from two organs, the foot and the gills, were sampled in the bathymodiolin mussels. The abdomen was sampled in shrimp species and legs in Segonzacia crabs. For smaller species, whole individuals (polynoid, spionid and Amathys lutzi polychaetes, pycnogonids) or pooled samples containing numerous individuals (copepods, amphipods, gastropods) were analyzed. Gastropods were acidified with a few drops of $\mathrm{HCl}(4.75 \mathrm{~N})$ prior to lyophilization to eliminate carbonate shells.

\subsubsection{Carbon and nitrogen stable isotope analysis}

After tissue collection, each sample was lyophilized and homogenized with a mortar and pestle. For carbon and nitrogen analyses, approximately $1 \mathrm{mg}$ of dry material was weighed in tin capsules. Each sample was prepared in duplicate and analyzed on a Eurovector elemental analyzer coupled to an Isoprime stable isotope-ratio mass spectrometer (EAIRMS, GV Instruments). Three certified (IAEA-CH-6 Sucrose, $\delta^{13} \mathrm{C}=-10.45 \pm 0.03 \%$; IAEA$\mathrm{N}$-1-ammonium sulfate, $\delta^{15} \mathrm{~N}=0.43 \pm 0.05 \%$ ) and laboratory standards ( $\beta$-alanine from Sigma-Aldrich, standardized in-house against several certified materials, $\delta^{13} \mathrm{C}=-26.08 \pm$ $0.22 \%$, $\delta^{15} \mathrm{~N}=-2.24 \pm 0.17 \%$ ) were inserted between series of 6 to 8 samples. The precision obtained for the standards was about $0.2 \%$ for both carbon and nitrogen. All values are expressed in $\delta$ (delta) notation with respect to VPDB $\left(\delta^{13} \mathrm{C}\right)$ and air $\left(\delta^{15} \mathrm{~N}\right)$ :

$\delta X(\%)=\left[\left(\boldsymbol{R}_{\text {sample }}-\boldsymbol{R}_{\text {standard }}\right)-1\right] \times 10^{3}$ where $R_{\text {sample }}$ is the isotope ratio in the sample and $\mathrm{R}_{\text {standard }}$ is the isotope ratio for a known standard. 


\subsubsection{Sulfur stable isotope analysis}

Sulfur stable isotopes were analyzed on a supplemental sample of 30 mussels. Twenty of these mussels came from two locations (C2 and $\mathrm{C} 10)$ characterized by high TdS concentrations $(\sim 34 \mu \mathrm{M}$, Table 1$)$ and 10 came from a location with a low TdS concentration (C1, $1.3 \mu \mathrm{M}$, Table 1). Gill and foot tissues were isolated, deep-frozen, lyophilized and ground into a fine powder. Ground samples were re-suspended in distilled water, shaken for $5 \mathrm{~min}$, centrifuged and the supernatant discarded to fully remove the sulfate present in the seawater (Kharlamenko et al. 2001). This process was repeated three times and finally the samples were re-dried, ground and sent to Iso-Analytical Limited in the United Kingdom for analysis. Each sample was prepared in duplicate in tin capsules containing reference or sample material plus vanadium pentoxide catalyst and analyzed on an elemental analyzer coupled to a stable isotope ratio mass spectrometer (EA-IRMS). The reference material used for sulfur-34 analysis was IA-R036 (Iso-Analytical working standard $\mathrm{BaSO}_{4}, \delta^{34} \mathrm{~S}_{\mathrm{V}-\mathrm{CDT}}=$ $+20.74 \%$ ). IA-R025 (Iso-Analytical working standard $\mathrm{BaSO}_{4}, \delta^{34} \mathrm{~S}_{\mathrm{V}-\mathrm{CDT}}=+8.53 \%$ ), IA-R026 (Iso-Analytical working standard $\mathrm{Ag}_{2} \mathrm{~S}, \delta^{34} \mathrm{~S}_{\mathrm{V}-\mathrm{CDT}}=+3.96 \%$ ) and IA-R036 were used for calibration and correction of the ${ }^{18} \mathrm{O}$ contribution to the SO+ ion beam. Samples of IA-R036, IA-R027 (Iso-Analytical working standard whale baleen, $\delta^{34} \mathrm{~S}_{\mathrm{v}-\mathrm{CDT}}=+16.30 \%$ ) and IAEA-SO$5\left(\mathrm{BaSO}_{4}, \delta^{34} \mathrm{~S}_{\mathrm{CDT}}=+0.5 \%\right)$ were measured for quality control during analysis. Working standards are traceable to NBS-127 $\left(\mathrm{BaSO}_{4}, \delta^{34} \mathrm{~S}_{\mathrm{CDT}}=+20.3 \%\right)$ and IAEA-S-1 $\left(\mathrm{Ag}_{2} \mathrm{~S}, \delta^{34} \mathrm{~S}_{\mathrm{V}}\right.$ $\mathrm{CDT}=-0.3 \%$ ). NBS-127, IAEA-S-1 and IAEA-SO-5 are distributed as isotope reference standards, by the International Atomic Energy Agency (IAEA), Vienna. All values are expressed in $\delta$ (delta) notation with respect to the primary international reference standard Vienna - Canyon Diablo Troilite or V-CDT, using the same equation as above.

Since the preparation method does not fully remove the elemental sulfur that accumulates as storage granules in the symbiont-containing tissues (i.e. gills) of the mussels (Lechaire et al. 2008), analyses were done on two different organs (foot and gills). The results can be used to quantify the amount of elemental sulfur stored in the gills compared to the foot and to assess the influence of elemental sulfur on the measured $\delta^{34} S$ values. In addition to sulfur, parallel carbon and nitrogen analyses were carried out for the 30 individuals.

\subsection{Data analysis}

\subsubsection{Environmental conditions}

To characterize each location, the average value of five environmental variables was determined. Geometric averages were used for the log-scale $\mathrm{pH}$ values. Because conditions around vents depend largely on the dilution of the hot hydrothermal fluid with colder surrounding seawater, temperature and chemical variables are often highly correlated. Kendall rank correlations were used to evaluate the intensity of these relationships and to select the variables that were best suited to explain the variation in trophic structure. Principal Component Analysis (PCA) and a three-group k-means partitioning on the standardized variables were used to illustrate among-location variation in environmental conditions and the linear correlations between the variables. Here and elsewhere, we used non-parametric methods when appropriate due to small sample size, non-linear relationships, or possible non-normal distributions. Linear methods were used when the frequency distribution of variables was sufficiently symmetric.

\subsubsection{Effect of tissue type and preservation method}

Potential differences in isotopic signatures between foot and gill tissues were assessed with Wilcoxon matched-pairs tests. The carbon, nitrogen and sulfur isotopic signatures of the 30 supplemental mussels from locations $\mathrm{C} 2, \mathrm{C} 10$ and $\mathrm{C} 1$ were used for that purpose. The effect of preservation method (freezing versus formalin/alcohol) on $\delta^{13} \mathrm{C}$ and $\delta^{15} \mathrm{~N}$ tissue signatures was investigated on taxa for which enough samples were available. 


\subsubsection{Morphology and isotopic signature of Bathymodiolus azoricus}

The Kendall rank correlations between the three morphometric variables measured on sampled mussels were computed and tested. These results allow determining whether all, or only a subset, of these variables should be used for further analysis. Kendall rank correlations were then used to investigate whether the carbon and nitrogen isotope signatures of $B$. azoricus individuals varied with the retained morphometric variables.

\subsubsection{Bathymodiolus azoricus and Branchipolynoe seepensis}

Two groups of Branchipolynoe seepensis worms were analyzed in this study. The first group included all individuals found inside sampled mussels ("internal" group), while the second consisted of all individuals found within the faunal samples but not inside mussels ("external" group). It is impossible to know with confidence if individuals from the external group came from inside or outside the collected mussels. A Mann-Whitney $U$ test was used to detect differences in the average carbon and nitrogen signatures for the two groups. Furthermore, Wilcoxon matched-pairs tests were used to test whether mussels and their associated $B$. seepensis (i.e. "internal" group) had significantly different isotopic signatures.

\subsubsection{Trophic relationships on Tour Eiffel}

The classic trophic shift guidelines found in the literature were followed to assess the trophic relationships at Tour Eiffel (DeNiro and Epstein 1978, Minagawa and Wada 1984, Vander Zanden and Rasmussen 2001). For $\delta^{13} \mathrm{C}$, a difference of $1 \%$ was assumed to correspond to a shift in one trophic level. Some authors propose different corrections depending on the tissue analyzed (shift of $0.3 \%$ for whole animal versus $1.3 \%$ for muscle) or on the treatment done prior to the analysis (-0.2\% when acidified, McCutchan et al. 2003). However, analyses done by McCutchan et al. (2003) used terrestrial insects with a chitin exoskeleton. Lorrain et al. (2002) propose a systematic analysis of different tissues for all species from their study and suggest that each tissue integrates different information. Unfortunately, this could not be done here owing to the limited number of available samples. Others correct their data according to a baseline corresponding to primary producers (tubeworms) in the vent ecosystem (Limen et al. 2007). This was not applicable in this study due to the multiplicity of feeding strategies in B. azoricus (Fiala-Medioni et al. 2002, Duperron et al. 2006).

For $\delta^{15} \mathrm{~N}$ values, we considered that a difference of a $3.4 \%$ indicated a shift between successive trophic levels knowing that different shifts may be more appropriate depending on the animal's diet: $1.4 \%$ for taxa with invertebrate diets and 3.3\% for consumers with microbial diets (Bergquist et al. 2007). Here, the nutritional modes of the different taxa are often unknown and microbes play a major role in the vent food web, justifying the use of a $\sim 3.4 \%$ shift for most species.

Finally, some authors have suggested that species with generalist feeding strategies may have higher $\delta^{13} \mathrm{C}$ variances than specialists (Limén and Juniper 2006, Bergquist et al. 2007). This hypothesis was tested using the Fligner-Killeen statistic and a permutation procedure to assess whether species showed significant differences of variances.

\subsubsection{Links between isotopic signatures and environmental conditions}

To test if nitrogen and carbon isotope signatures varied with environmental conditions, Kendall rank correlations were used. Mean environmental variables were used for each location. The test was performed for all taxa pooled in the same dataset, and separately for taxonomic groups with sufficient sample size to detect an effect at type I error rate of $\alpha=0.05$. A Holm correction for multiple testing was applied to all $p$ values. 
Finally, for all microhabitats for which isotope data was available for the structuring species $B$. azoricus, we used redundancy analysis (RDA) to model the relationship between the morphology and isotope signatures of mussels on the one hand, and selected environmental variables on the other. We used the mean values for each location and all variables were standardized prior to analyses. Locations were also submitted to a three-group k-means partitioning based on isotopic and morphological data.

\subsubsection{Among-location variability in isotopic signatures}

To compare among-location variability in $\delta^{13} \mathrm{C}$ and $\delta^{15} \mathrm{~N}$ for species with sufficient sampling, a Kruskal-Wallis test was performed. Pairwise diffrences were identified a posteriori with the Behrens-Fisher non-parametric multiple comparison test.

All analyses were performed using the $R$ language ( $R$ Development Core Team 2008). The vegan package (Oksanen et al. 2008) was used for multivariate analyses and the ggplot2 package (Wickham 2008) for some of the plotting.

\section{Results}

\subsection{Environmental conditions}

Mean environmental conditions at each location (microhabitat) are summarized in Table 1. Mean temperatures varied from $4.79^{\circ} \mathrm{C}$ to $8.79^{\circ} \mathrm{C}$, a relatively narrow temperature range for this ecosystem. The temperature measured at $1700 \mathrm{~m}$ depth, away from the hydrothermal influence is $4.4^{\circ} \mathrm{C}$ within the same area. The microhabitats with the warmest temperature values (C2, C8 and C10) also had the highest concentrations of TdFe and TdS. On the other hand, the coolest location C9 had one of the lowest TdS and TdFe concentrations. TdFe and TdS thus showed a pattern of variation similar to temperature. All environmental variables were significantly correlated to temperature (Table 1, bottom panel). However, while sulfide and iron concentrations were positively correlated with temperature, $\mathrm{TdCu}$ and $\mathrm{pH}$ showed negative correlations. The highest $\mathrm{TdCu}$ concentrations were found in low temperature locations C9 and C12 (Table 1). Figure 2 shows the linear correlations between environmental variables. The result of the three-group k-means partitioning is superimposed on the PCA to highlight the differences among the locations. These groups are distributed mainly on the first axis that accounts for $80 \%$ of the variance. Given the strong correlations between temperature, $\mathrm{TdS}, \mathrm{TdFe}$ and $\mathrm{pH}$, only temperature was used in subsequent analyses. Although significantly correlated to temperature, $\mathrm{TdCu}$ concentrations behave somewhat differently from the other variables. For this reason, we decided to include it in the RDA. The existence of a secondary TdCu source has been hypothesized at Tour Eiffel (Sarradin et al. 2009). These authors suggested that the increase of dissolved copper could correspond to the oxidative redissolution of copper sulfide particles formed in the vicinity of the fluid exit.

\subsection{Faunal composition}

B. azoricus covers large surfaces on the Tour Eiffel hydrothermal edifice and acts as a structuring species for many other taxa. The most dominant taxa from the 12 microhabitats underwent isotopic analyses (Table 2). The total relative abundance of analyzed taxa ranges from a minimum of $17.9 \%$ (C5) to a maximum of $91.4 \%$ (C3, Sarrazin et al. in prep.). The unrepresented taxa were most often meiofaunal species such as copepods (C2, C4, C5, C6 and C10) and mussel larvae (C9). For the small fauna, the available material was insufficient to carry out isotopic analyses using the methods selected for this work. 


\subsection{Effect of tissue type and preservation method}

A significant difference between gill and foot $\delta^{34} S$ values in the 30 supplemental $B$. azoricus was found by Wilcoxon matched-pairs tests ( $C 1$ : V $=53, p=0.006$; $C 2$ : $V=53, p=0.006$; $C 10$ : $\mathrm{V}=54, p=0.004)$. The amount of elemental sulfur stored in the gills was slightly higher $(+1.4 \%)$ than in the foot.

In the sulfide-rich microhabitats, no significant differences were found for mean $\delta^{15} \mathrm{~N}$ values from feet and gills (C2: $\mathrm{V}=10, p=0.084 ; \mathrm{C} 10: \mathrm{V}=13, p=0.160)$ or $\delta^{13} \mathrm{C}$ in $\mathrm{C} 10$ individuals $(\mathrm{V}=21, p=0.557)$. Mussels from $\mathrm{C} 2$ showed significant differences in the $\delta^{13} \mathrm{C}$ signature between both organs $(\mathrm{V}=0, p=0.002)$ with the gills being more depleted than the feet by $\mathrm{a}$ mean of $1.44 \%$. In $\mathrm{C} 1$, both $\delta^{13} \mathrm{C}$ and $\delta^{15} \mathrm{~N}$ varied significantly between the two tissues $\left(\delta^{13} \mathrm{C}\right.$ : $\mathrm{V}=1, p=0.004 ; \delta^{15} \mathrm{~N}: \mathrm{V}=0, p=0.002$ ) with the gills being more depleted than the feet by $\mathrm{a}$ mean of $1.19 \%$ in both cases.

Sampling was performed as uniformly as possible across all microhabitats, with an equal number of gills and feet from different individuals collected in each location, with a few exceptions (Table 2). This balanced sampling allows to confidently pool isotopic data for the main data set $(n=99)$ despite between-tissue differences. Thus, our study focuses on the variability among microhabitats rather than among tissues. Therefore, pooling isotope values for both tissues provides more accurate data than relying on either gills or feet alone.

Due to very small sample size, it is impossible to statistically test the effect of preservation methods on $\delta^{13} \mathrm{C}$ and $\delta^{15} \mathrm{~N}$ signatures (Table 3) but overall, no consistent enrichment or depletion trend was observed in our data. Negligible effects have been reported in previous studies at vents (Bergquist et al. 2007) and in other types of ecosystems (Arrington and Winemiller 2002, Syväranta et al. 2008). Moreover, the isotopic signatures we found for alcohol preserved samples were close to the values found by Colaço et al. (2002a) with frozen samples at Tour Eiffel ( $A$. lutzi, pynogonids) and other vent sites (amphipods, $L$. atlanticus). The scarcity of data and the absence of a general trend between the two preservation methods led us to include all data, regardless of the methods.

\subsection{Morphology and isotopic signature of B. azoricus}

Correlations between the three morphological variables measured on 97 (out of 99) mussels were highly significant (Kendall, $\mathrm{T}=0.88$ between length and width, $\mathrm{T}=0.90$ between length and thickness and $\mathrm{T}=0.88$ between width and thickness, all $\mathrm{p}<0.001$ ). Only mussel length was used as a measure of size in subsequent analyses. $B$. azoricus at Tour Eiffel displayed a wide range of isotopic compositions ranging from -15.29 to $-34.35 \%$ or $\delta^{13} \mathrm{C}$ and from 16.15 to $-0.29 \%$ for $\delta^{15} \mathrm{~N}$. While most individual mussels have $\delta^{13} \mathrm{C}$ values lower than $-25 \%$, six individuals from five microhabitats exhibit $\delta^{13} \mathrm{C}$ values between -22.33 and $-15.29 \%$ (Table 2). We have observed a significant correlation between carbon and nitrogen isotope ratios and mussel length (Fig. 3, $\delta 13 \mathrm{C}: \mathrm{T}=0.40, p<0.001 ; \delta 15 \mathrm{~N}: \mathrm{T}=0.29, \mathrm{p}<0.001$ ) for the global study $(n=97)$. This correlation was not significant $(p>0.05)$ for the 30 supplemental individual mussels but it should be noted that this sample only contained mussels with a length greater than $47.4 \mathrm{~mm}$.

\subsection{Bathymodiolus azoricus and Branchipolynoe seepensis}

No significant difference between the isotopic signatures of the two groups ("internal" and "external") of $B$. seepensis were found by Mann-Whitney $U$ tests $\left(\delta^{13} C: Z=-0.1787, p=0.865\right.$; $\delta^{15} \mathrm{~N}$ : $\left.Z=-0.2645, p=0.798\right) . \delta^{13} \mathrm{C}$ values for both groups of $B$. seepensis closely matched those of $B$. azoricus, but the $\delta^{15} \mathrm{~N}$ signature was higher in $B$. seepensis. Likewise, no significant difference between the $\delta^{13} \mathrm{C}$ values of 16 mussels and their associated polynoidae were found by a Wilcoxon matched-pairs test ("internal" group; $V=60, p=0.710$ ). However, a 
significant difference was found for $\delta^{15} \mathrm{~N}$ signatures $(\mathrm{V}=0, p<0.001)$ with $B$. seepensis tissues being, on average, enriched by $3.9 \%$ relative to their hosts.

\subsection{Trophic relationships on Tour Eiffel}

To get an overall view of the trophic relationships among dominant taxonomic groups of the Tour Eiffel edifice, mean $\delta^{15} \mathrm{~N}$ values of each taxon were plotted against their corresponding mean $\delta^{13} \mathrm{C}$ values. Two trophic groups were identified from this representation (Fig. 4A). A close-up of the second group (IIb) gives a more detailed view of the interactions between the different taxa (Fig. 4B). Overall, the shifts proposed by other authors (McCutchan et al. 2003, Bergquist et al. 2007) gave similar conclusions as those observed on the figures.

The family Tegastidae (copepods) had the most depleted $\delta^{13} \mathrm{C}$ values (mean of $-37.42 \%$ ) and intermediate $\delta^{15} \mathrm{~N}$ values (mean of 2.82\%o). B. azoricus mussels and their commensal polychaetes $B$. seepensis showed very negative $\delta^{13} C(-29.97$ and $-29.18 \%$ respectively) and $\delta^{15} \mathrm{~N}(-11.27$ and $-6.94 \%$ ) isotopic values (Table 2, Fig. 4B). Mirocaris fortunata and Chorocaris chacei shrimps had the most enriched isotopic signatures (Fig. 4A). C. chacei displayed isotopic values ranging from -11.67 to $-26.86 \%$ for $\delta^{13} \mathrm{C}$ and from 7.32 to $-2.13 \%$ for $\delta^{15} \mathrm{~N}$ while $M$. fortunata displayed isotopic signatures varying from -11.77 to $-23.61 \%$ for $\delta^{13} \mathrm{C}$ and from 1.29 to $8.53 \%$ for $\delta^{15} \mathrm{~N}$. With the exception of one extreme $\delta^{13} \mathrm{C}$ value ($26.86 \%$ ), C. chacei showed narrower ranges than $M$. fortunata for both isotopes. The gastropods Lepetodrilus atlanticus, Pseudorimula midatlantica, Lirapex costellata and $P$. valvatoides presented wide ranges of $\delta^{13} \mathrm{C}(-29.82$ to $-14.33 \%)$ and $\delta^{15} \mathrm{~N}(-0.42$ to $5.89 \%)$ values (Fig. 4A). The polychaetes $A$. lutzi and those in the Spionidae family presented similar $\delta^{13} \mathrm{C}$ mean values but $A$. lutzi displayed a wider range of $\delta^{13} \mathrm{C}$ ranging from -32.65 to 16.95\% (Fig. 4A). Amphipods displayed intermediate $\delta^{13} \mathrm{C}$ values (mean of $-21.04 \%$ ) but had lower $\delta^{15} \mathrm{~N}$ values (mean of $-0.47 \%$ ) compared to the other species. S. mesatlantica crabs displayed a wide range of isotopic signatures ranging from -17.56 to $-23.24 \%$ for $\delta^{13} \mathrm{C}$ and from -0.09 to $4.33 \%$ for $\delta^{15} \mathrm{~N}$.

Significant differences in the variance of $\delta^{13} \mathrm{C}$ signatures were observed $\left(\chi_{0}^{2}=24.43, p=0.003\right.$, 9999 permutations) for species sampled on at least 5 microhabitats. Three groups can be tentatively inferred: 1 ) those with important (SD $>4 \%$ ) variations in $\delta^{13} \mathrm{C}$ signatures (Amathys lutzi and Branchipolynoe seepensis); 2) those with intermediate $(3 \%<\mathrm{SD}<4 \%)$ variations in $\delta^{13} \mathrm{C}$ signatures (Chorocaris chacei, Bathymodiolus azoricus, Mirocaris fortunata, and Protolira valvatoides) and, 3) those with low $\left(\mathrm{SD}<3 \%\right.$ ) variation in $\delta^{13} \mathrm{C}$ signatures (Segonzacia mesatlantica).

\subsection{Relationships between isotopic signature and environmental conditions}

Significant, positive relationships between carbon and nitrogen isotope ratios of $B$. azoricus mussels and the temperature measured in their habitats were revealed by Kendall rank correlations (Table 4). Similar positive correlations were also found in the $B$. seepensis polychaetes (Table 4). In $M$. fortunata, only $\delta^{13} \mathrm{C}$ was significantly correlated with temperature. Interestingly, the $\delta^{13} \mathrm{C}$ and $\delta^{15} \mathrm{~N}$ values in $P$. valvatoides gastropods were negatively correlated with this variable. This species was found only in a narrow range of temperatures (Table 4) in relatively cold microhabitats (C1, C3, C4, C5 and C11, Table 2). Non-significant correlations were obtained for both isotopes in the remaining species $(S$. mesatlantica, A. lutzi and C. chacei). After pooling together all individuals from all the groups presented in Table 4, a significant positive correlation was found between both isotopic ratios $\left(\delta^{13} \mathrm{C}\right.$ and $\left.\delta^{15} \mathrm{~N}\right)$ and temperature (Table 4). However, although every effort was made to uniformly collect isotopic data on the dominant taxonomic groups in each microhabitat, some sampling bias was inevitably introduced in this last analysis.

Carbon and nitrogen isotope data was available for $B$. azoricus in all microhabitats except C9 (Table 2). A canonical redundancy analysis show that variations in temperature and $\mathrm{TdCu}$ explain variations in size and isotopic signatures of mussels (Fig. 5, pseudo- $F=3.3915$, $p=0.046$ ). The two canonical axes contained $45.88 \%$ of the total variance, but a significant 
proportion of that was attributed to the first axis only (pseudo- $\mathrm{F}=6.5392, p=0.039$ ). The second canonical axis only explained $1.65 \%$ of total variance and was not significant when controlling for the first axis (pseudo- $\mathrm{F}=0.2437, p=0.820$ ). Likewise, controlling for effect of temperature (pseudo- $\mathrm{F}=5.8652, p=0.030$ ) rendered $\mathrm{Cu}$ non-significant (pseudo- $\mathrm{F}=0.9177$, $p=0.430$ ). Finally, the three-groups $k$-means partitioning obtained with isotopic and length data from $B$. azoricus was not strictly congruent with the one obtained from environmental variables (Figs. 2 and 5) even after removing microhabitat C9 from the environmental analysis (not shown). These results jointly support the hypothesis of the influence of environmental conditions on mussel isotopic signatures.

\subsection{Among-microhabitat variability in isotopic signatures}

Among-microhabitat variability in carbon and nitrogen isotope ratios was plotted for species for which at least two individuals were analyzed on a minimum of four locations (microhabitats, Fig. 6). With the exception of $M$. fortunata, there were significant variations between locations (Table 5). Nevertheless, a similar trend was observed for this species.

Pairwise comparisons results are given in an alternate version of Figure 6 available as an online supplement. For $A$. Lutzi, nearly all differences where significant, with no discernable pattern. In $B$. azoricus, the $\delta^{15} \mathrm{~N}$ values from the coldest microhabitat (C12) were responsible for most of the significant differences, while values from microhabitats in the $5.11-5.55^{\circ} \mathrm{C}$ range $\left(C 5, C 3\right.$ and $C 7$ ) also contributed to differences in $\delta^{13} C$. Likewise, in $B$. seepensis, values from these same microhabitats accounted for the vast majority of differences for both isotopes.

The sulfur isotopic analyses, performed on the $30 \mathrm{~B}$. azoricus individuals from locations $\mathrm{C} 1$, $\mathrm{C} 2$ and $\mathrm{C} 10$, gave $\delta^{34} \mathrm{~S}$ values ranging from 1.29 to $5.44 \%$. However, no significant differences were found between these microhabitats regardless of tissue (feet: $\mathrm{H}=1.4348$, $p=0.488$; gills: $\mathrm{H}=5.101, p=0.078)$.

\section{Discussion}

\subsection{Trophic relationships on Tour Eiffel}

The $\delta^{15} \mathrm{~N}$ versus $\delta^{13} \mathrm{C}$ plot for all the samples collected in this study (Fig. 4A) were similar to that obtained in Colaço et al. (2002a). A diagonal pattern with very negative $\delta^{13} \mathrm{C}$ and $\delta^{15} \mathrm{~N}$ values in one corner (mussels and polynoids) and less negative $\delta^{13} \mathrm{C}$ and positive $\delta^{15} \mathrm{~N}$ values in the opposite corner (shrimps) was observed. Nevertheless, in the present study, tegastid copepods exhibited extremely negative $\delta^{13} \mathrm{C}$ values compared to the other taxa.

Two distinct trophic groups could be distinguished in the mussel assemblages of the Tour Eiffel edifice (Fig. 4A). The first group (group I) was composed of B. azoricus and their associated $B$. seepensis polychaetes and is linked to direct relationships with mussel endosymbionts. The second group (group II) consisted of heterotrophic species and is linked to the consumption of a wide variety of organic carbon sources. This group is divided in two sub-groups. Group Ila includes tegastid copepods while group IIb comprises all the other taxa (bacterivores, detritivores, scavengers).

\subsubsection{Carbon sources}

Isotopic data on potential food sources in chemosynthetic ecosystems are scarce, due in particular to the difficulty of obtaining good quality samples. Among the potential food sources for the chemoautotrophic microorganisms are dissolved inorganic carbon sources from pelagic and hydrothermal origins (Karl 1995). Most vent habitats are enriched in total 
dissolved inorganic carbon (DIC, $\mathrm{CO}_{2}+\mathrm{HCO}_{3}+\mathrm{CO}_{3}{ }^{2-}$ ) and bicarbonate is the dominant inorganic C species in seawater (Karl 1995). Great physiological diversity exists among microorganisms and a variety of carbon and energy sources can be used for their metabolism (Karl 1995). Several autotrophic pathways reduce $\mathrm{CO}_{2}$ to produce organic matter. The Calvin-Benson cycle is one of the most widely used pathways for $\mathrm{CO}_{2}$ assimilation by autotrophs in oxic conditions. At vents, alternative pathways may be favored and induce large variations in isotopic signatures of carbon sources. These pathways include the ribulose monophosphate pathway (RuMP), the serine pathway, the carbamyl phosphate synthetase pathway and the acetyl coenzyme A (COA) pathways. The latter includes two separate pathways: the rTCA cycle (reductive tricarboxylic acid) and the noncyclic reductive acetyl CoA pathway. The rTCA cycle and the Calvin-Benson cycle are considered the principal carbon fixation pathways in the hydrothermal ecosystem (Campbell and Cary 2004). As an example, differences in the isotopic discrimination of the two forms of the ribulose bisphosphate carboxylase oxygenase enzyme (RuBisCO, Robinson and Cavanaugh 1995) may explain the enriched $\delta^{13} \mathrm{C}$ composition of hydrothermal shrimp species (Rieley et al. 1999, Colaço et al. 2002a). Since both enzymes fractionate to different extents against ${ }^{13} \mathrm{C}$, carbon sources derived from sulfide oxidation by type II RuBisCO display different $\delta^{13} \mathrm{C}$ values than those derived by type I RuBisCO (see values in Fig. 4A).

Non-symbiotic primary consumers are assumed to rely on free-living chemoautotrophic bacteria as their main food source (Limen et al. 2007). These free-living microbes appear to contain a great diversity of microorganisms, using different metabolic processes ( $\mathrm{V}$. Crépeau, pers. comm.). In addition to microbes, DOM and POM from pelagic and detrital origins constitute significant nutritional resources for filter feeders, detritus feeders and scavengers. The vent habitat appears to be characterized by an important small-scale variability in such food sources (Limen et al. 2007), probably strongly influencing species distribution. Although they were not identified in this study, the large range of $\delta^{13} \mathrm{C}$ values observed inside group II $(-37.42$ to $-11.67 \%$ ) suggests the existence of a large pool of carbon sources at Tour Eiffel. The isotope values fall within the range (-41 to -16\%) reported by Trask and Van Dover (1999) for free-living bacteria living in mats.

\subsubsection{Symbiont-bearing fauna (group I)}

Duperron et al. (2006) showed that $B$. azoricus benefits from dual symbiosis with sulfur- and methane-oxidizing bacteria. This species has also retained a functional gut and the ability to filter feed (Fiala-Médioni et al. 2002, Colaço et al. 2007). The wide range of isotopic values obtained for $B$. azoricus at Tour Eiffel $\left(-15.29\right.$ to $-34.35 \%$ o $\delta^{13} \mathrm{C}$ and from -16.15 to $-0.29 \%$ $\delta^{15} \mathrm{~N}$ ) was similar to those found by others (Trask and Van Dover 1999, Colaço et al. 2002a). In light of their various potential feeding modes, the carbon isotope signatures of Bathymodiolus mussels were expected to vary between -30 and $-36 \%$ for those relying mostly on their thiotrophic endosymbionts (Trask and Van Dover 1999). $\delta^{13} \mathrm{C}$ values for filter feeding mussels are expected to fall within the ranges obtained for vent POM (-16.7 to 24.6\%, Limen et al. 2007) and POM from the open ocean (-15 to $-25 \%$, Desbruyères et al. 1983, Kennicutt II et al. 1992). Finally, values between -22 and $-28 \%$ should be obtained for mussels that rely mostly on methanotrophic symbionts (Pond et al. 1998). Most of the mussels analyzed in this study displayed $\delta^{13} \mathrm{C}$ values between $-27 \%$ and $-34 \%$, suggesting that $B$. azoricus at Tour Eiffel probably relied on both endosymbionts for its nutritional requirements, with a dominant contribution of sulfur-oxidizing bacteria. Individuals with values higher than $-25 \%$ were rare, suggesting that filter feeding remains a secondary mode of nutrition. These results do not support the prediction of Martins et al. (2008) model in which the predominant nutritional pathway varies from a strong dependency on filter feeding in small mussels to a total reliance on endosymbiosis in larger individuals.

Mussels with enriched isotopic signatures $\left(\delta^{13} \mathrm{C}>-25 \%\right.$ ) have previously been found in the Lucky Strike vent field, but never on the Tour Eiffel edifice (Trask and Van Dover 1999, 
Colaço et al. 2002a). However, this may be explained by the greater sampling effort carried out on a smaller area in the present study. Surprisingly, the six "enriched" mussels were found in five different locations, along with individuals with a depleted signature. This intraspecific variability may be attributed to the use of different carbon sources (DOM, POM), to the relative proportion of the two symbionts and/or to the intervention of different metabolic pathways (Calvin-Benson cycle, rTCA cycle). The nutritional plasticity observed within Bathymodiolus mussels probably facilitates their colonization of different types of microhabitats (Pond et al. 1998) and would explain the success of this genus on MAR vents and within chemosynthetic ecosystems.

Our analysis revealed that mussel length was positively correlated with temperature as well as $\delta^{13} \mathrm{C}$ and $\delta^{15} \mathrm{~N}$ isotope signatures (Fig. 3). This not only suggests that larger mussels may thrive better in warmer microhabitats, but also that they might achieve this by relying more on their methanotrophic, rather than their thiotrophic endosymbionts, as corroborated by their $\delta^{13} \mathrm{C}$ values (-22 to $-28 \%$ ). These results agree with the conclusions of Halary et al. (2008) who found variation in the relative abundance of symbionts in response to different environmental conditions from the same locations. Thus, most mussels found at the cooler temperatures were small and showed $\delta^{13} \mathrm{C}$ values typical of those relying primarily on their thiotrophic endosymbionts (-30 to $-36 \%$ ). A spatial segregation of mussel sizes in relation to environmental conditions has been reported in other studies (Comtet and Desbruyères 1998, Sarradin et al. 1998, Martins et al. 2008). According to Martins et al. (2008), the observed spatial distribution of the vent mussels may reflect the higher dependency of larger mytilids on endosymbiotic pathways and, consequently, on their proximity to sources of reduced substrates. On the other hand, this spatial segregation may also indicate a lower tolerance of larvae, juveniles and smaller mussels to harsher conditions. Adult mussels may be more tolerant and migrate to microhabitats where fluid conditions are more favorable to their symbionts.

Thiotrophic endosymbiosis seemed to be favoured at low temperatures. Whether this is due to the relative efficiency of microorganisms within the mussels or to the specific chemical forms $\left(\mathrm{H}_{2} \mathrm{~S}\right.$ and/or $\left.\mathrm{HS}^{-}\right)$available in these conditions remains an open question. As temperature increases along the gradient, the decrease in $\mathrm{pH}$ should modify the chemical speciation of sulfide compounds with a shift from $\mathrm{HS}^{-}$to $\mathrm{H}_{2} \mathrm{~S}$ species (Le Bris et al. 2006). If thiotrophic symbionts rely more on this chemical form, they will be limited by its availability along the gradient. This will also change the relative availability of $\mathrm{HS}^{-}$to methane for $B$. azoricus and its symbionts. Our data support this hypothesis since small mussels seemed to rely primarily on thiotrophy and were found in the cooler microhabitats.

Regardless of microhabitats, all $\delta^{34} S$ values were less than $5 \%$, indicative of a nutrition mode primarily based on thiotrophy (Vetter and Fry 1998). $\delta^{34} \mathrm{~S}$ values for methanotrophic mussels would have varied between 8 and 13\%o (Vetter and Fry 1998, Dattagupta et al. 2004). Significant differences in $\delta^{34} S$ values were observed in two species of vent mussels harbouring either methanotroph or thiotroph endosymbionts (Naraoka et al. 2008). Methanotroph mussels (B. platifrons) had $\delta^{34} S$ values ranging from 11.1 to $13.9 \%$ while for thiotrophic mussels (B. septemdierum), the $\delta^{34} S$ signature was $4.3 \%$ (Naraoka et al. 2008). The integrative property of $\delta^{34} S$ isotopic signature is unknown and should be investigated. In the present study, we only observed a slight enrichment in $\delta^{34} S$ values in $B$. azoricus gills. While it is still unclear at this point, a shift towards methanotrophy in larger mussels might first be visible in the gills which host the symbionts.

The close association linking $B$. seepensis polynoids with $B$. azoricus is well known. While this polychaete has been long considered as a commensal species, recent studies have shown that the gills of infested mussels can be damaged by the worm, suggesting at least a semi-parasitic relationship (Britayev et al. 2003a, b, 2007). Polynoid-mussel associations are seen in all mussel size classes (Britayev et al. 2007). While females are found within the mussels, males can also be present outside, within the environment (Jollivet et al. 2000, Britayev et al. 2007, Plouviez et al. 2008). Thus, males and females have different spatial 
distribution and may use different food sources. As expected, specimens of $B$. seepensis found inside the mussels (i.e. the "internal" group) displayed $\delta^{13} \mathrm{C}$ values very similar to $B$. azoricus but higher $\delta^{15} \mathrm{~N}$ values, reflecting an increment of one trophic level (mean of $+3.9 \%$, Fig. 4A). Similar data were obtained for the "external" $B$. seepensis group, except for three individuals showing enriched isotopic signatures $\left(\delta^{13} C=-17.71,-17.55\right.$ and $-13.20 \%$; $\delta^{15} \mathrm{~N}=4.65,2.37$ and $7.54 \%$ respectively). The first two $\delta^{13} \mathrm{C}$ and $\delta^{15} \mathrm{~N}$ values can be attributed to signatures from individuals living inside enriched mussels. However, the third enriched value in $\delta^{13} \mathrm{C}(-13.20 \%)$ does not correspond to any observed or reported mussel signature. We surmise that this individual was living in the surrounding environment and relying on different food sources. Overall, these data are concordant with the results of other studies (Trask and Van Dover 1999, Colaço et al. 2002a) and suggest that B. seepensis depend primarily on $B$. azoricus as its food source. It is not known whether $B$. seepensis directly eats mussel tissue or feeds on mussel detritus (Trask and Van Dover 1999).

Apart from $B$. seepensis, none of the analyzed species appear to feed on the symbiontbearing species $B$. azoricus despite the fact that it has probably the highest biomass on the edifice and may represents a potentially important food source. S. mesatlantica crabs have often been observed feeding on accidentally broken mussels, but this particular interaction was not apparent within stable isotope signatures. It is not known whether this behaviour is only anecdotal or if mussels are a regular part of the crab's diet. Nevertheless, our isotope data only consider adult mussels (length $\geq 20 \mathrm{~mm}$ ). Isotope data from larval $(500 \mu \mathrm{m})$ and post-larval $(0.7-1.4 \mathrm{~mm})$ stages show that both had enriched $\delta^{13} \mathrm{C}$ and $\delta^{15} \mathrm{~N}$ values compared to the adults (Trask and Van Dover 1999). This suggests that $B$. azoricus recruits may be potential preys for vent species, for instance the crab Segonzacia mesatlantica.

\subsubsection{Heterotrophic fauna (groups IIa and IIb)}

\subsubsection{Copepods (group Ila)}

Data on the isotopic signatures of hydrothermal copepods are quite rare, principally because of the small amount of material available for isotopic analyses. The copepod samples analyzed in this study (Tegastidae) had $\delta^{13} \mathrm{C}$ signatures very similar ( $\pm 1 \%$ ) to the minimum value found for the so-called "filamentous bacteria" sampled on the same edifice by Colaço et al. (2002a, Fig. 4A). In addition, its $\delta^{15} \mathrm{~N}$ value was $3-4 \%$ o heavier than the maximum values observed for these bacteria. The extremely low $\delta^{13} \mathrm{C}$ values obtained for the "filamentous bacteria" by Colaço et al. (2002a) led us to suppose that this sample may contain microbes with different metabolic pathways. While filamentous bacteria alone are usually sulfide oxidizers, samples probably contain a whole community of microorganisms. Indeed, preliminary results from Tour Eiffel microbial mats indicate the possible presence of methanotrophs (V. Crépeau, pers. comm.).

Tegastid copepods may rely on free-living bacteria, as suggested by Heptner and Ivanenko (2002). The presence of bacterial filaments near the mouth parts of copepods from our samples supports this hypothesis (Ivanenko, pers. comm.). In addition, microhabitats that harbor large densities of copepods (C3, C4 and C5) were covered by dense white material mats that appear to be filamentous microbes. Based on the fatty acid levels in different species of siphonostomatoid copepods from Northeast Pacific vents, a recent study showed that bacteria constitute a significant part of the copepod diets (Limén et al. 2008). The very negative carbon values found in our sample may also be the result of an unknown endosymbiotic association with the copepod. Further analyses on copepods and their potential food sources should help determine their feeding modes.

The contribution of copepod remains to the detrital pool of vent habitats needs to be quantified as they may constitute an important food source when present in very high 
densities (Limén et al. 2008). Curiously, as is the case for mussels, no predator appeared to directly specialize on this abundant resource.

\subsubsection{Other heterotrophs (group IIb)}

Bacterivores- The gastropod $L$. atlanticus and amphipods had similar $\delta^{15} \mathrm{~N}$ and $\delta^{13} \mathrm{C}$ isotope signatures and were found at the base of this trophic group, probably just above primary producers (Fig. 4B). It has been hypothesized that $L$. atlanticus and amphipods graze on bacteria (Colaço et al. 2002a, Dando et al. 2006). Unfortunately, their food sources were not analyzed in our study.

Detritivores - L. costellata, pycnogonids, $P$. valvatoides, spionids, A. lutzi and Pseudorimula midatlantica form a large and intricate group (Fig. 4B). Most of these species are known to be detritus-feeders (Desbruyères et al. 2006, Colaço et al. 2007), with the exception of pycnogonids which have been reported to feed on bacteria (Brescia and Tunnicliffe 1998, Bergquist et al. 2007) and P. midatlantica for which nothing is known. Because their $\delta^{15} \mathrm{~N}$ values were greater than those of the two bacterivorous taxa (L. atlanticus and amphipods), we hypothesize that this group of species are detritus feeders. Their wide range of $\delta^{13} \mathrm{C}$ and $\delta^{15} \mathrm{~N}$ values suggests that they have a mixed diet of detritus and microbes.

The ubiquitous species $A$. lutzi has colonized all known hydrothermal vents from the MAR (Desbruyères et al. 2006). It was found in all the microhabitats studied here (but only analyzed in $67 \%$ of them because of its low relative abundance in some locations). It showed significant variation in $\delta^{13} \mathrm{C}$ isotope signatures among locations. A. lutzi was the taxon for which $\delta^{13} \mathrm{C}$ exhibited the largest variance. In addition, this species is one of the three taxa for which there is no relationship between isotopic signature and environmental conditions, despite its presence in a wide range of conditions. As most ampharetids, it has external buccal tentacles that can be used to scrape surface deposits (Desbruyères and Laubier 1996). Together, these results support the hypothesis that $A$. lutzi feeds on multiple sources depending on food availability and the intensity of the competition. Such opportunistic behavior could explain its overall success in the vent environment.

Scavengers- $M$. fortunata and $C$. chacei are the only two shrimp species found at Tour Eiffel. They share similar isotopic signatures, distinct from all other species analyzed in this study (Fig. 4A). Their isolated localization in the Tour Eiffel trophic chain suggests that their food sources were not analyzed in this study. However, their high $\delta^{15} \mathrm{~N}$ values support the hypothesis that both species may be predators and/or scavengers, most likely consuming individuals that feed on free-living bacteria (Segonzac et al. 1993, Gebruk et al. 2000, Colaço et al. 2002a, 2007). Furthermore, as proposed by other authors (Gebruk et al. 2000, Colaço et al. 2002a), it is unlikely that adult mussels represent a significant portion of their food sources since both $\delta^{13} \mathrm{C}$ and $\delta^{15} \mathrm{~N}$ values were too dissimilar to those found in mussels. Finally, our data do not support the predator-prey relationship between the two shrimp species inferred by Colaço et al. (2002a).

The overlapping isotopic signatures of the two Tour Eiffel vent shrimp species suggest that they could be in competition for food resources. To minimize competition, the two species probably experience subtle niche partitioning by using different feeding strategies, living in distinct environmental conditions or exploiting the resources differently. Our data showed that $M$. fortunata colonized a wider range of water temperatures and metal concentrations than $C$. chacei, which was restricted to slightly warmer habitats $\left(+0.5^{\circ} \mathrm{C}\right)$. Indeed, M. fortunata was present in $75 \%$ of the microhabitats while $C$. chacei was found in only $42 \%$ of the locations, always in association with $M$. fortunata. 
Putative predator- Our mean isotopic values for S. mesatlantica (mean $\delta^{13} \mathrm{C},-19.96 \%$; mean $\delta^{15} \mathrm{~N}, 2 \%$ (Fig. 4B) fell within the lower range of the values obtained by Colaço et al. (2002a) with much larger samples sizes ( $n=20$ against $n=6$ in this study). No predator-prey relationships between $S$. mesatlantica and mussels or shrimps were detected in our data set. Nevertheless, a predator-prey relationship appears to link S. mesatlantica and amphipods. This result is consistent with lipid fatty acid content analyses by Colaço et al. (2007) who demonstrated that instead of being omnivorous, as suggested previously, S. mesatlantica appears to be a predator, feeding on bacterivorous species. In shallow hydrothermal vents, crabs are known to scavenge on dead zooplankton (Jeng et al. 2004). However, the depleted $\delta^{15} \mathrm{~N}$ isotope values may suggest nutrition based on free-living microbes. This feeding mode has been reported for another vent crab species Bythograea thermydron which appears to quickly colonize bacterial mats that develop after an eruption (DeBevoise et al. 1990).

\subsection{Relationship between isotopic signatures and environmental factors}

Many authors have reported indirect links between isotopic composition and abiotic conditions at vents. Limén and Juniper (2006) have shown differences in $\delta^{13} \mathrm{C}$ values between three sites of differing hydrothermal activity. The site with milder environmental conditions (mussel bed) was characterized by broader sources of primary production than the two high fluid flow sites. Links between fluid flow intensity and the diet of different copepod species have also been observed (Limén et al. 2008). Thus, copepods living closest to fluid source appear to have a diet dominated by autotrophic bacteria while species living further away display a mixed diet, probably autotrophic and heterotrophic bacteria (Limén et al. 2008). At a larger spatial scale, Colaço et al. (2002b) showed that $\mathrm{H}_{2} \mathrm{~S}$ and $\mathrm{CH}_{4}$ endmember fluid concentrations, through their direct influence on the relative contribution of mussel endosymbionts, could explain field-scale variation in mussel $\delta^{13} \mathrm{C}$ signatures. At the scale of a single vent field, the presence of a bimodal distribution in $\delta^{13} \mathrm{C}$ mussel isotopic compositions (enriched and depleted groups) was explained by the presence of local heterogeneity of fluid composition (Trask and Van Dover 1999, Colaço et al. 2002a). We identified a small group of mussels probably relying on filter-feeding. Their distribution was not related to environmental conditions and they occurred haphazardly in different microhabitats from the same edifice.

The food web structure of the Tour Eiffel hydrothermal edifice showed small-scale variations that could be attributed to variation in local food source availability as reported by Limén et al. (2007), to environmental conditions or to specific feeding strategies. In this study, a strong significant relationship was observed between $\delta^{13} \mathrm{C}$ and $\delta^{15} \mathrm{~N}$ isotope signatures and environmental conditions for four hydrothemal species (B. azoricus, $B$. seepensis, $M$. fortunata, $P$. valvatoides) while for others (S. mesatlantica, A. lutzi, C. chacei), no significant relationship was observed. Temperature was the variable retained here, but the significant relationships detected may actually be due to any other environmental condition that is correlated with it (TdS, TdFe, TdCu, $\mathrm{pH}$ and/or unmeasured variables). The negative relationship between the isotopic signatures of $P$. valvatoides and temperature is intriguing. Interestingly, this species was not found in the hottest microhabitats which may suggest that this gastropod species has a limited tolerance to hydrothermal fluid emissions, but relies on organic detritus provided by the vent assemblages.

Abiotic conditions can have a strong impact on trophic relationships, especially in an ecosystem driven by autotrophic microbial production. Evidence for the direct influence of hydrothermal fluid characteristics on the diversity and activity of vent primary producers is growing, but is often limited to the hottest part of the vent ecosystem (A. Godfroy, pers. comm.). Sievert et al. (2000) showed an increase in the abundance of bacteria and Archaea along a thermal gradient, indicating that microbial activity is stimulated by high temperatures and vent fluid flow. A clear influence of fluid flow intensity on the development of biofilms at vents was also reported by Guezennec et al. (1998). Two recent studies have shown a correlation between the relative microbial abundance or the volume occupied by 
endosymbionts and environmental conditions (Salerno et al. 2005, Halary et al. 2008). The availability and nature of potential electron donors in the end-member fluids seem to influence the occurrence of different metabolic pathways in the microbial pool. For example, pulses of sulfur-rich fluids can trigger an increase in total volume and proportion of sulfuroxidizing symbionts in B. azoricus mussels (Halary et al. 2008). In the light of our results, we suggest that vent fluid characteristics, through their strong influence on microbial production at small spatial-scales, are key factors in variation of local carbon sources at Tour Eiffel.

\subsection{Variation in isotopic signature among microhabitats}

Finally, the data obtained in this work revealed high spatial variability in isotopic signatures within single species at the scale of one sulfide edifice. This inter-microhabitat variability was observed for three out of four species tested (B. azoricus, B. seepensis, $A$. lutzi). For $M$. fortunata, the variability observed between the different microhabitats was almost significant (Table 5). If the environmental conditions are not significantly linked to the isotopic compositions of a particular taxa, other factors such as the utilization of several food sources by the same species may explain variation among microhabitats. This result is important to consider when comparing isotopic signatures from different sites and at different spatial scales. Whether the patterns observed for $B$. azoricus assemblages on Tour Eiffel are the same on other active hydrothermal edifices in the Lucky Strike vent field remains to be elucidated.

The use of the variance of $\delta^{13} \mathrm{C}$ signatures has been proposed to assess different feeding strategies (Limen and Juniper 2006, Bergquist et al. 2007). However, the results obtained here are rather mitigated. In most case this variance is directly linked to the variations of environmental conditions in different microhabitats $(B$. azoricus, $B$. seepensis, $M$. fortunata, $P$. valvatoides), reflecting or not variations in the breadth of the trophic niches. When no such relationship is observed ( $A$. lutzi, $C$. chacei, S. mesatlantica), $\delta^{13} \mathrm{C}$ variances may indicate different feeding strategies (generalist versus specialist). A high variance in $\delta^{13} \mathrm{C}$ could also result from a specialist diet on a generalist prey (Bergquist et al. 2007). The use of $\delta^{13} \mathrm{C}$ variances alone may not be the best tool to assess feeding strategies at vents.

\section{Conclusions}

Overall, this study has shown that there was significant spatial variation in stable isotope signatures of the different species at Tour Eiffel and that this variation was significantly linked to variations in environmental conditions. This confirms the hypothesis raised by several authors on the role of hydrothermal fluids on the trophic network at small spatial scales.

The isotopic composition of total organic carbon in tissues gives an integrated measure of all carbon sources assimilated by the organism over its lifetime. However, stable isotope measurements alone -especially when a variety of food sources come into play- are of limited use for identifying specific dietary sources (Rieley et al. 1999, Limén et al. 2008). Fatty acid analyses can complement isotopic signature analyses as they provide information on the relative proportions of several dietary components (Pond et al. 1998, Rieley et al. 1999, Colaço et al. 2007, Limén et al. 2008). They can also be used to determine the nature of carbon sources at vents (Stevens et al. 2008), to evaluate the role of photosynthetically derived carbon in the nutrition of vent species (Rieley et al. 1999) or to uncover hostsymbiont relationships (Pranal et al. 1996, Pond et al. 1997a, b, Colaço et al. 2007, Limen et al. 2008, Naraoka et al. 2008). Using fatty acid biomarkers, future studies should help resolve several questions raised in this study such as the nature of the enigmatic polynoidmussel association, the presence of mussels in the diet of $S$. mesatlantica or the possible endosymbiotic activity in tegastid copepods. 
Finally, even if the two trophic groups identified seemed to have almost no relationship with one another, it must be kept in mind that entire faunal compartments are missing from this study. More studies on the isotopic signatures of small meiofauna and microbial communities, particularly those of free-living microorganisms, are necessary to better define the trophic relationships in different vent assemblages. Meiofauna may represent an important link to higher trophic levels and may significantly contribute to the complexity of the vent food web (Limén et al. 2008). The functional roles of the different communities of microorganisms in the processing and degradation of POM in the hydrothermal ecosystem also need to be assessed.

\section{Acknowledgments}

We would like to thank Captain Philippe Guillemet of the R/V Pourquoi pas? and his crew for their never-failing collaboration in the success of the MoMARETO cruise. We are also grateful to the Victor 6000 ROV pilots for their patience and constant support. The English was professionally edited by Carolyn Engel-Gautier. This work was done with the financial support of the European Union EXOCET/D (FP6-GOCE-CT-2003-505342) and MARBEF (FP6-GOCE-CT-2003-505446) projects, the ANR Deep Oases (ANR06 BDV005) and the GDR ECCHIS as well as by the CoML CHEsS project.

\section{References}

Arrington, D.A., Winemiller, K.O., 2002. Preservation effects on stable isotope analysis of fish muscle. Transactions of the American Fisheries Society 131 (2), 337-342.

Bergquist, D.C., Eckner, J.T., Urcuyo, I.A., Cordes, E.E., Hourdez, S., Macko, S.A., Fisher, C.R., 2007. Using stable isotopes and quantitative community characteristics to determine a local hydrothermal vent food web. Marine Ecology Progress Series 330, 49-65.

Brescia, L. A., V. Tunnicliffe, 1998. Population biology of two pycnogonid species (Fam. Ammotheidae) at hydrothermal vents in the Northeast Pacific. Cahiers de Biologie Marine 39, 233-237.

Britayev, T.A., Krylova, E.M., Aksyuk, T.S., Cosel, R., 2003a. Association of Atlantic hydrothermal mytilids of the genus Bathymodiolus spp. (Mollusca: Mytilidae) with the polychaete Branchipolynoe aff. seepensis (Polychaeta: Polynoidae): commensalism or parasitism? Doklady Biological Sciences 391, 371-374.

Britayev, T.A., Krylova, E.M., Martin, D., von Cosel, R., Aksiuk, T.S., 2003b. Symbiont-host interraction in the association of the scalworm Branchipolynoe aff.seepensis (Polychaeta: Polynoidae) with the hydrothermal mussel, Bathymodiolus spp. (Bivalvia: Mytilidae). InterRidge News 12 (2), 13-16.

Britayev, T.A., Martin, D., Krylova, E.M., Von Cosel, R., Aksiuk, T.S., 2007. Life-history traits of the symbiotic scale-worm Branchipolynoe seepensis and its relationships with host mussels of the genus Bathymodiolus from hydrothermal vents. Marine Ecology 28 (1), 36-48. Campbell, B. J., Cary, S. C., 2004. Abundance of reverse tricarboxylic acid cycle genes in free-living microorganisms at deep-sea hydrothermal vents. Applied and Environmental Microbiology 70 (10), 6282-6289.

Charlou, J.-L., Donval, J.-P., Douville, E., Jean-Baptiste, P., Radford-Knoery, J., Fouquet, Y., Dapoigny, A., Stievenard, M., 2000. Compared geochemical signatures and the evolution of Menez Gwen $\left(37^{\circ} 50^{\prime} \mathrm{N}\right)$ and Lucky Strike $\left(37^{\circ} 17^{\prime} \mathrm{N}\right)$ hydrothermal fluids, south of the Azores Triple Junction on the Mid-Atlantic Ridge. Chemical Geology 171, 49-75.

Childress, J.J., Fisher, C.R., 1992. The biology of hydrothermal vent animals: Physiology, biochemistry, and autotrophic symbioses. Oceanography and Marine Biology Annual Review 30 (4044), 337-441. 
Colaço, A., Desbruyères, D., Comtet, T., Alayse, A.M., 1998. Ecology of the Menez Gwen hydrothermal vent field (Mid-Atlantic Ridge/Azores Triple Junction). Cahiers de Biologie Marine 39, 237-240.

Colaço, A., Dehairs, F., Desbruyères, D., 2002a. Nutritional relations of deep-sea hydrothermal fields at the Mid-Atlantic Ridge: a stable isotope approach. Deep-Sea Research I 49, 395-412.

Colaço, A., Dehairs, F., Desbruyères, D., Bris, N.L., Sarradin, P.-M., 2002b. $\delta^{13} C$ signature of hydrothermal mussels is related with the end-member fluid concentrations of $\mathrm{H}_{2} \mathrm{~S}$ and $\mathrm{CH}_{4}$ at the Mid-Atlantic Ridge hydrothermal vent fields. Cahiers de Biologie Marine 43 (3-4), 259262.

Colaço, A., Desbruyeres, D., Guezennec, J., 2007. Polar lipid fatty acids as indicators of trophic associations in a deep-sea vent system community. Marine Ecology 28, 15-24.

Comtet, T., Desbruyères, D., 1998. Population structure and recruitment in mytilid bivalves from the Lucky Strike and Menez Gwen hydrothermal vent fields $\left(37^{\circ} 17^{\prime} \mathrm{N}\right.$ and $37^{\circ} 50^{\prime} \mathrm{N}$ on the Mid-Atlantic Ridge). Marine Ecology Progress Series 163, 165-177.

Conway, N.M., Kennicutt, M.C., Van Dover, C.L., 1994. Stable isotopes in the study of marine chemosynthetic-based ecosystems. Blackwell scientific publications, London.

Dando, P.R., Pendlebury, S., Nortley, H.K., 2006. Behaviour and nutrition of the MAR vent limpet Lepetodrilus atlanticus (Waren \& Bouchet 2001). 11. International Deep-Sea Biology Symposium, Southampton, (UK), 9-14 july 2006. National Oceanography Centre, Southampton, UK, p. 41.

Dattagupta, S., Bergquist, D.C., Szalai, E.B., Macko, S.A., Fisher, C.R., 2004. Tissue carbon, nitrogen, and sulfur stable isotope turnover in transplanted Bathymodiolus childressi mussels: Relation to growth and physiological condition. Limnology and Oceanography 49 (4), 1144-1151.

DeBevoise, A.E., Childress, J.J., Withers, N.W., 1990. Carotenoids indicate differences in diet of the hydrothermal vent crab Bythograea thermydron (Brachyura). Marine Biology 105, 109-115.

DeNiro, M.J., Epstein, S., 1978. Influence of diet on the distribution of carbon isotopes in animals. Geochimica et Cosmochimica Acta 42 (5), 495-506.

Desbruyères, D., Gaill, F., Laubier, L., Prieur, D., Rau, G., 1983. Unusual nutrition of the "Pompeii worm" Alvinella pompejana (polychaetous annelid) from a hydrothermal vent environment: SEM, TEM, ${ }^{13} \mathrm{C}$ and ${ }^{15} \mathrm{~N}$ evidence. Marine Biology $75,201-205$.

Desbruyères, D., Laubier, L., 1996. A new genus and species of ampharetid polychaete from deep-sea hydrothermal vent community in the Azores triple-junction area. Proceedings of the Biological Society of Washington 109 (2), 248-255.

Desbruyères, D., Biscoito, M., Caprais, J.-C., Colaço, A., Comtet, T., Crassous, P., Fouquet, Y., Khripounoff, A., Le Bris, N., Olu, K., Riso, R., Sarradin, P.-M., Segonzac, M., Vangriesheim, A., 2001. Variations in deep-sea hydrothermal vent communities on the MidAtlantic Ridge when approaching the Azores Plateau. Deep-Sea Research I 48, 1325-1346.

Desbruyères, D., Segonzac, M., Bright, M., 2006. Handbook of deep-sea hydrothermal vent fauna. Landesmuseen, Linz.

Duperron, S., Bergin, C., Zielinski, F., Blazejak, A., Pernthaler, A., McKiness, Z.P., DeChaine, E., Cavanaugh, C.M., Dubilier, N., 2006. A dual symbiosis shared by two mussel species, Bathymodiolus azoricus and Bathymodiolus puteoserpentis (Bivalvia: Mytilidae), from hydrothermal vents along the northern Mid-Atlantic Ridge. Environmental Microbiology 8 (8), 1441-1447.

Fiala-Médioni, a., McKiness, Z.P., Dando, P., Boulegue, J., Mariotti, A., Alayse-Danet, A.M., Robinson, J.J., Cavanaugh, C.M., 2002. Ultrastructural, biochemical and immunological characterization of two populations of the mytilid mussel Bathymodiolus azoricus from the Mid-Atlantic Ridge: evidence for a dual symbiosis. Marine Biology 141, 1035-1043.

Fisher, C.R., Childress, J.J., Oremland, R.S., Bidigare, R.R., 1987. The importance of methane and thiosulphate in the metabolism of the bacterial symbionts of two deep-sea mussels. Marine Biology 96, 59-71.

Fisher, C.R., Kennicutt II, M.C., Brooks, J.M., 1990. Stable carbon isotopic evidence for carbon limitation in hydrothermal vent vestimentiferans. Science 247, 1094-1096. 
Fisher, C.R., Childress, J.J., Macko, S.A., Brooks, J.M., 1994. Nutritional interactions in Galapagos Rift hydrothermal vent communities: inferences from stable carbon and nitrogen isotope analyses. Marine Ecology Progress Series 103, 45-55.

Fouquet, Y., Ondréas, H., Charlou, J.-L., Donval, J.-P., Radford-Knoery, J., Costa, I., Lourenço, N., Tivey, M.K., 1995. Atlantic lava lakes and hot vents. Nature 377, 201.

Gebruk, A.V., Southward, E.C., Kennedy, H., Southward, A.J., 2000. Food sources, behaviour, and distribution of hydrothermal vent shrimps at the Mid-Atlantic Ridge. Journal of the Marine Biological Association of UK 80, 485-499.

Guezennec, J., Ortega-Morales, O., Raguenes, G., Geesey, G., 1998. Bacterial colonization of artificial substrate in the vicinity of deep-sea hydrothermal vents. FEMS Microbiology Ecology 26 (2), 89-99.

Halary, S., Riou, V., Gaill, F., Boudier, T., Duperron, S., 2008. 3D FISH for the quantification of methane- and sulphur-oxidizing endosymbionts in bacteriocytes of the hydrothermal vent mussel Bathymodiolus azoricus. The ISME Journal 2 (3), 284-292.

Heptner, M.V., Ivanenko, V.N., 2002. Copepoda (Crustacea) of hydrothermal ecosystems of the World Ocean. Arthropoda Selecta 11 (2), 117-134.

Jannasch, H.W., 1985. The chemosynthetic support of life and the microbial diversity at deep-sea hydrothermal vents. Proceedings of the Royal Society of London Series BBiological Sciences 225 (1240), 277-297.

Jannasch, H.W., 1989. Chemosynthetically sustained ecosystems in the deep sea. In: Schlegel, H.G., Bowien, B. (Eds.), Autotrophic Bacteria. Springer Verlag, Berlin, pp. 147-166. Jeng, M.S., Ng, N.K., Ng, P.K.L., 2004. Feeding behaviour: Hydrothermal vent crabs feast on sea 'snow'. Nature 432 (7020), 969-969.

Jollivet, D., Empis, A., Baker, M.C., Hourdez, S., Comtet, T., Jouin-Toulmond, C., Desbruyères, D., Tyler, P.A., 2000. Reproductive biology, sexual dimorphism and population structure of the deep-sea hydrothermal vent scale-worm, Branchipolynoe seepensis (Polychaeta: Polynoidae). Journal of the Marine Biological Association of the U. K. 80, 55-68. Karl, D.M., 1995. Ecology of free-living, hydrothermal vent microbial communities. In: Karl, D.M. (Eds.), The microbiology of deep-sea hydrothermal vents. CRC Press Inc. pp. 35-124.

Kennicutt II, M.C., Burke Jr, R.A., Mac Donald, I.R., Brooks, J.M., Denoux, G.J., Macko, S.A., 1992. Stable isotope partitioning in seep and vent organisms: chemical and ecological significance. Chemical Geology 101, 293-310.

Kharlamenko, V.I., Kiyashko, S.I., Imbs, A.B., Vyshkvartzev, D.I., 2001. Identification of food sources of invertebrates from the seagrass Zostera marina community using carbon and sulfur stable isotope ratio and fatty acid analyses. Marine Ecology Progress Series 220, 103117.

Le Bris, N., Rodier, P., Sarradin, P.M., Le Gall, C., 2006. Is temperature a good proxy for sulfide in hydrothermal vent habitats. Cahiers de Biologie Marine 47, 465-470.

Lechaire, J.-P., Frébourg, G., Gaill, F., Gros, O., 2008. In situ characterization of sulphur in gill-endosymbionts of the shallow water lucinid Codakia orbicularis (Linné, 1758) by highpressure cryofixation and EFTEM microanalysis. Marine Biology 154 (4), 693-700.

Levesque, C., Kim Juniper, S., Limén, H., 2006. Spatial organization of food webs along habitat gradients at deep-sea hydrothermal vents on Axial Volcano, Northeast Pacific. Deep Sea Research Part I: Oceanographic Research Papers 53 (4), 726-739.

Levin, L.A., Michener, R.H., 2002. Isotopic evidence for chemosynthesis-based nutrition of macrobenthos: The lightness of being at Pacific methane seeps. Limnology and Oceanography 47 (5), 1336-1345.

Limén, H., Juniper, S., 2006. Habitat controls on vent food webs at Eifuku Volcano, Mariana Arc. Cahiers de biologie marine. 47 (4), 449-455.

Limén, H., Levesque, C., Juniper, K., 2007. POM in macro-/meiofaunal food webs associated with three flow regimes at deep-sea hydrothermal vents on Axial Volcano, Juan de Fuca Ridge. Marine Biology 153, 129-139.

Limén, H., Stevens, C.J., Bourass, Z., Juniper, S.K., 2008. Trophic ecology of siphonostomatoid copepods at deep-sea hydrothermal vents in the northeast Pacific. Marine Ecology Progress Series 359, 161-170. 
Lorrain, A., Paulet, Y.-M., Chauvaud, L., Savoye, N., Donval, A., Saout, C., 2002. Differential $\delta^{13} \mathrm{C}$ and $\delta^{15} \mathrm{~N}$ signatures among scallop tissues: implications for ecology and physiology. Journal of Experimental Marine Biology and Ecology 275 (1), 47-61.

Luther, G.W., Rozan, T.F., Taillefert, M., Nuzzio, D.B., Meo, C.D., Shank, T.M., Lutz, R.A., Cary, S.C., 2001. Chemical speciation drives hydrothermal vent ecology. Nature 410, 813816.

Martins, I., Colaço, A., Dando, P.R., Martins, I., Desbruyères, D., Sarradin, P.-M., Marques, J.C., Serrão-Santos, R., 2008. Size-dependent variations on the nutritional pathway of Bathymodiolus azoricus demonstrated by a C-flux model. Ecological Modelling 217 (1-2), 5971.

McCutchan, J.H., Lewis, W.M., Kendall, C., McGrath, C.C., 2003. Variation in trophic shift for stable isotope ratios of carbon, nitrogen, and sulfur. Oikos 102 (2), 378-390.

Micheli, F., Peterson, C.H., Mullineaux, L.S., Fisher, C.R., Mills, S.W., Sancho, G., Johnson, G.A., Lenihan, H.S., 2002. Predation structures communities at deep-sea hydrothermal vents. Ecological Monographs 72 (3), 365-382.

Minagawa, M., Wada, E., 1984. Stepwise enrichment of $\delta^{15} \mathrm{~N}$ along food chains: Further evidence and the relation between $\delta^{15} \mathrm{~N}$ and animal age. Geochimica et Cosmochimica Acta 48 (5), 1135-1140.

Naraoka, H., Naito, T., Yamanaka, T., Tsunogai, U., Fujikura, K., 2008. A multi-isotope study of deep-sea mussels at three different hydrothermal vent sites in the northwestern Pacific. Chemical Geology 255, 25-32.

Ondreas, H., Cannat, M., Fouquet, Y., Normand, A., Sarradin, P.M., Sarrazin, J., in press. Recent volcanic events and the distribution of hydrothermal venting at the Lucky Strike hydrothermal field, Mid-Atlantic Ridge, Geochemistry. Geophysics. Geosystems.

Oksanen, J., Kindt, R., Legendre, P., O'Hara, B., Simpson, G.L., Stevens, M.H.H., Wagner, $\mathrm{H}$., 2008. vegan: Community Ecology Package. R package version 1.13-2.

Plouviez, S., Daguin-Thiébaut, C., Hourdez, S., Jollivet, D., 2008. Juvenile and adult scale worms Branchipolynoe seepensis in Lucky Strike hydrothermal vent mussels are genetically unrelated. Aquatic Biology 3, 79-87.

Polz, M.F., Robinson, J.J., Cavanaugh, C.M., Van Dover, C.L., 1998. Trophic ecology of massive shrimp aggregations at a Mid-Atlantic Ridge hydrothermal vent site. Limnology and Oceanography 43 (7), 1631-1638.

Pond, D.W., Dixon, D.R., Bell, M.V., Fallick, A.E., Sargent, J.R., 1997a. Occurence of 16:2(n4) and 18:2(n-4) fatty acids in the lipids of the hydrothermal vent shrimps Rimicaris exoculata and Alvinocaris markensis: nutritional and trophic implications. Marine Ecology Progress Series 156, 167-174.

Pond, D.W., Segonzac, M., Bell, M.V., Dixon, D.R., Fallick, A.E., Sargent, J.R., 1997b. Lipid and lipid carbon stable isotope composition of the hydrothermal vent shrimp Mirocaris fortunata: evidence for nutritional dependence on photosynthetically fixed carbon. Marine Ecology Progress Series 257, 221-231.

Pond, D.W., Bell, M.V., Dixon, D.R., Fallick, A.E., Segonzac, M., Sargent, J.R., 1998. Stablecarbon-isotope composition of fatty acids in hydrothermal vent mussels containing methanotrophic and thiotrophic bacterial endosymbionts. Applied and Environmental Microbiology 64 (1), 370-375.

Pranal, V., Fiala-Medioni, A., Guezennec, J., 1996. Fatty acid characteristics in two symbiotic gastropods from a deep hydrothermal vent of the west Pacific. Marine Ecology Progress Series 142 (1-3), 175-184.

R Development Core Team, 2008. R: A language and environment for statistical computing. R Foundation for Statistical Computing, Vienna, Austria.

Rau, G.H., 1981a. Hydrothermal vent clam and tubeworm ${ }^{13} \mathrm{C} /{ }^{12} \mathrm{C}$ : further evidence of non photosynthetic food sources. Science 213, 338-340.

Rau, G.H., 1981b. Low ${ }^{15} \mathrm{~N} /{ }^{14} \mathrm{~N}$ in hydrothermal vent animals: ecological implications. Nature 289, 484-485.

Rau, G.H., Hedges, J.I., 1979. Carbon-13 depletion in a hydrothermal vent mussel: suggestion of a chemosynthetic food source. Science 203, 648-649. 
Rieley, G., Van Dover, C.L., Hedrick, D.B., Eglinton, G., 1999. Trophic ecology of Rimicaris exoculata: a combined lipid abundance/stable isotope approach. Marine Biology 133, 495499.

Riso, R.D., Le Corre, P., Chaumery, C.J., 1997. Rapid and simultaneous analysis of trace metals $(\mathrm{Cu}, \mathrm{Pb}$, and $\mathrm{Cd})$ in seawater by potentiometric stripping analysis. Analytica Chimica Acta 351, 83-89.

Robinson, J.J., Cavanaugh, C.M., 1995. Expression of form I and form II Rubisco in chemoautotrophic symbioses: Implications for the interpretation of stable carbon isotope values. Limnology and Oceanography 40 (8), 1496-1502.

Robinson, J.J., Polz, M.F., Fiala-Medioni, A., Cavanaugh, C.M., 1998. Physiological and immunological evidence for two distinct C1-utilizing pathways in Bathymodiolus puteoserpentis (Bivalvia: Mytilidae), a dual endosymbiotic mussel from the Mid-Atlantic Ridge. Marine Biology 132 (4), 625-633.

Robinson, J.J., Scott, K.M., Swanson, S.T., O'Leary, M.H., Horken, K., Tabita, F.R., Cavanaugh, C.M., 2003. Kinetic isotope effect and characterization of form II RubisCO from the chemoautotrophic endosymbionts of the hydrothermal vent tubeworm Riftia pachyptila. Limnology and Oceanography 48 (1), 48-54.

Salerno, J.L., Macko, S.A., Hallam, S.J., Bright, M., Won, Y.-J., McKiness, Z., Dover, C.L.V., 2005. Characterization of symbiont populations in life-history stages of mussels from chemosynthetic environments. Biological Bulletin 208 (2), 145-155.

Sancho, G., Fisher, C.R., Mills, S., Micheli, F., Johnson, G.A., Lenihan, H.S., Peterson, C.H., Mullineaux, L.S., 2005. Selective predation by the zoarcid fish Thermarces cerberus at hydrothermal vents. Deep-Sea Research I 52, 837-844.

Sarradin, P.M., Caprais, J.C., Briand, P., Gaill, F., Shillito, B. Desbruyères, D., 1998. Chemical and thermal description of the environment of the Genesis hydrothermal vent community $\left(13^{\circ} \mathrm{N}, \mathrm{EPR}\right)$. Cahiers de Biologie Marine 39, 159-167.

Sarradin, P.M., Waeles, M., Bernagout, S., Le Gall, C., Sarrazin, J., Riso, R., 2009. Speciation of dissolved copper within an active hydrothermal edifice on the Lucky Strike vent field (MAR, $37^{\circ} \mathrm{N}$ ). Science of the Total Environment.407, 869-878.

Sarrazin, J., Juniper, S.K., Massoth, G., Legendre, P., 1999. Physical and chemical factors influencing species distributions on hydrothermal sulfide edifices of the Juan de Fuca Ridge, Northeast Pacific. Marine Ecology Progress Series 190, 89-112.

Sarrazin, J., Sarradin, P.M., the MoMARETO cruise participants. 2006. MoMARETO: a cruise dedicated to the spatio-temporal dynamics and the adaptations of hydrothermal vent fauna on the Mid-Atlantic Ridge. InterRidge News 15, 24-33.

Segonzac, M., de Saint Laurent, M., Casanova, B., 1993. L'énigme du comportement trophique des crevettes Alvinocarididae des sites hydrothermaux de la dorsale médioatlantique. Cahiers de Biologie Marine 34, 535-571.

Sievert, S.M., Ziebis, W., Kuever, J., Sahm, K., 2000. Relative abundance of Archaea and Bacteria along a thermal gradient of a shallow-water hydrothermal vent quantified by rRNA slot-blot hybridization. Microbiology-UK 146, 1287-1293.

Schmidt, C., Vuillemin, R., Le Gall, C., Gaill, F., Le Bris, N., 2008. Geochemical energy sources for microbial primary production in the environment of hydrothermal vent shrimps. Marine Chemistry 108, 18-31.

Southward, A.J., Southward, E.C., Spiro, B., Rau, G.H., Tunnicliffe, V., $1994 .{ }^{13} \mathrm{C} /{ }^{12} \mathrm{C}$ of organisms from Juan de Fuca ridge hydrothermal vents: a guide to carbon and food sources. Journal of Marine Biological Association of UK 74, 265-278.

Stevens, C.J., Limen, H., Pond, D.W., Gelinas, Y., Juniper, S.K., 2008. Ontogenetic shifts in the trophic ecology of two alvinocaridid shrimp species at hydrothermal vents on the Mariana Arc, western Pacific Ocean. Marine Ecology Progress Series 356, 225-237.

Suess, E., 1980. Particulate organic carbon flux in the oceans -surface productivity and oxygen utilization. Nature $288,260-263$. 
Syväranta, J., Vesala, S., Rask, M., Ruuhijärvi, J., Jones, R., 2008. Evaluating the utility of stable isotope analyses of archived freshwater sample materials. Hydrobiologia 600 (1), 121130.

Takai, K., Campbell, B.J., Cary, S.C., Suzuki, M., Oida, H., Nunoura, T., Hirayama, H., Nakagawa, S., Suzuki, Y., Inagaki, F., Horikoshi, K., 2005. Enzymatic and genetic characterization of carbon and energy metabolisms by deep-sea hydrothermal chemolithoautotrophic isolates of Epsilonproteobacteria. Applied and Environmental Microbiology 71 (11), 7310-7320.

Trask, J.L., Van Dover, C.L., 1999. Site-specific and ontogenetic variations in nutrition of mussels (Bathymodiolus sp.) from the Lucky Strike hydrothermal vent field, Mid-Atlantic Ridge. Limnology and Oceanography 44 (2), 334-343.

Tsurumi, M., Tunnicliffe, V., 2003. Tubeworm-associated communities at hydrothermal vents on the Juan de Fuca Ridge, northeast Pacific. Deep Sea Research I 50, 611-629.

Tunnicliffe, V., 1991. The biology of hydrothermal vents: Ecology and evolution. Oceanography and Marine Biology Annual Review 29, 319-407.

Tunnicliffe, V., Jensen, R.G., 1987. Distribution and behaviour of the spider crab Macroregonia macrochira Sakai (Brachyura) around the hydrothermal vents of the northeast Pacific. Canadian Journal of Zoology 65, 2443-2449.

Van Dover, C.L., Fry, B., Grassle, J.F., Humphris, S., Rona, P.A., 1988. Feeding biology of the shrimp Rimicaris exoculata at hydrothermal vents on the Mid-Atlantic Ridge. Marine Biology 98, 209-216.

Van Dover, C.L., Fry, B., 1989. Stable isotopic compositions of hydrothermal vent organisms. Marine Biology 102, 257-263.

Van Dover, C.L., Fry, B., 1994. Microorganisms as food resources at deep-sea hydrothermal vents. Limnology and Oceanography 39 (1), 51-57.

Van Dover, C.L., Trask, J.L., 2000. Diversity at deep-sea hydrothermal vent and intertidal mussel beds. Marine Ecology Progress Series 195, 169-178.

Vander Zanden, M.J., Rasmussen, J.B., 2001. Variation in delta N-15 and delta C-13 trophic fractionation: Implications for aquatic food web studies. Limnology and Oceanography 46 (8), 2061-2066.

Vereshchaka, A.L., Vinogradov, G.M., Lein, A.Y., Dalton, S., Dehairs, F., 2000. Carbon and nitrogen isotopic composition of the fauna from the Broken Spur hydrothermal vent field. Marine Biology 136, 11-17.

Vetter, R.D., Fry, B., 1998. Sulfur contents and sulfur-isotope compositions of thiotrophic symbioses in bivalve molluscs and vestimentiferan worms. Marine Biology 132, 453-460.

Voight, J.R., 2000. A deep-sea octopus (Graneledone cf. boreopacifica) as a shell-crushing hydrothermal vent predator. Journal of Zoological Society of London 252, 335-341.

Vuillemin, R., Le Roux, D., Dorval, P., Bucas, K., Sudreau, J.P., Hamon, M., Le Gall, C., Sarradin, P.M., in press. CHEMINI: a new in situ CHEmical MINIaturized analyzer. Deep Sea Research I.

Wickham, H., 2008. ggplot2: An implementation of the Grammar of Graphics. R package version 0.6

Zbinden, M., Shillito, B., Le Bris, N., de Villardi de Montlaur, C., Roussel, E., Guyot, F., Gaill, F., Cambon-Bonavita, M.-A., 2008. New insigths on the metabolic diversity among the epibiotic microbial communitiy of the hydrothermal shrimp Rimicaris exoculata. Journal of Experimental Marine Biology and Ecology 359 (2), 131-140. 


\section{Figures}

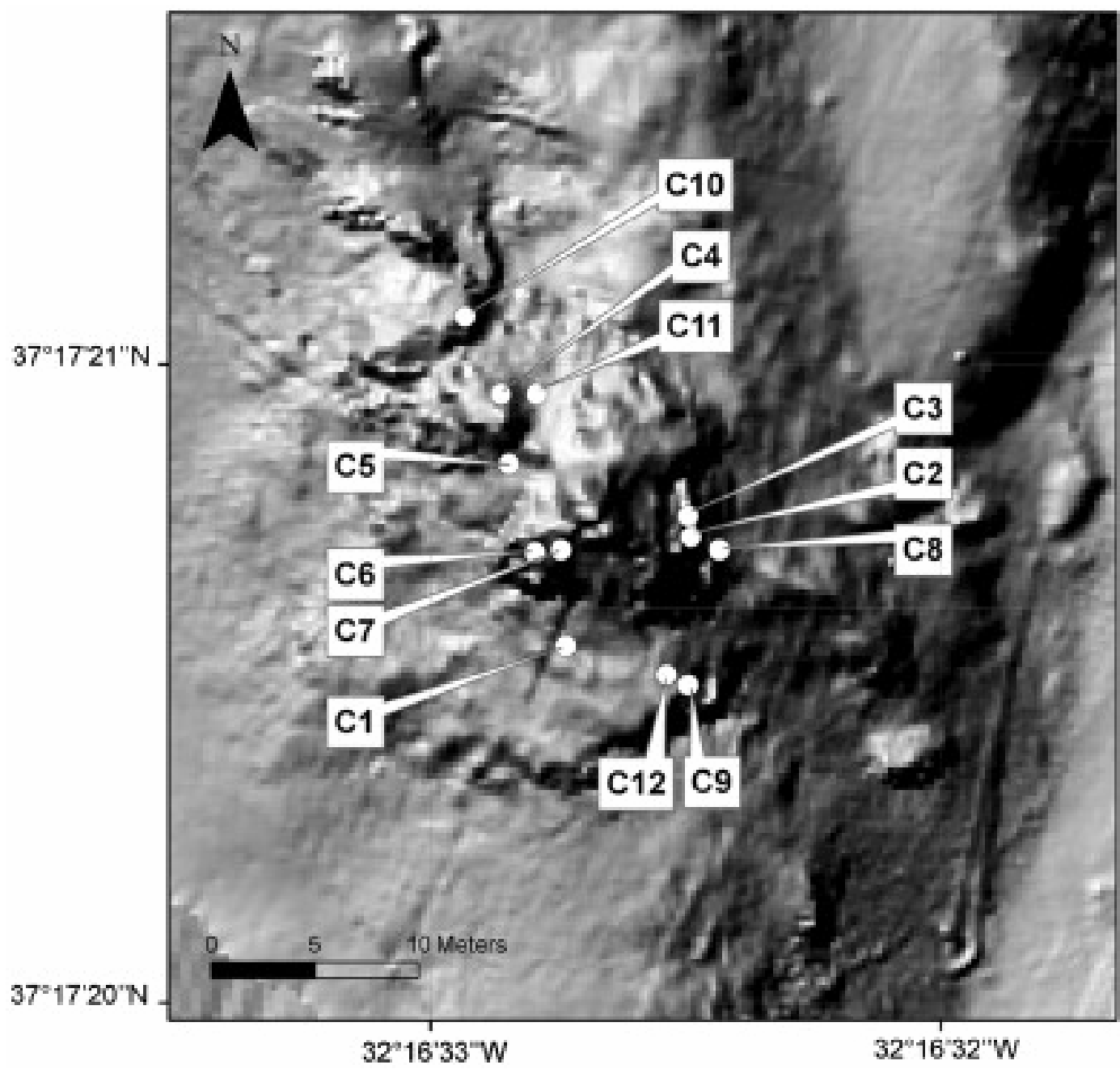

Fig. 1. High-resolution bathymetric map of the Tour Eiffel active edifice and position of the 12 sampled locations (Sarrazin et al. 2006). This $11 \mathrm{~m}$ high sulfide structure is located in the Lucky Strike vent field $\left(37^{\circ} 17.29^{\prime} \mathrm{N}, 32^{\circ} 16.45^{\prime} \mathrm{W}\right)$ on the Mid-Atlantic Ridge. Maximum distance between sampling locations is $21 \mathrm{~m}$ (between C9 \& C10); minimum distance is 50 cm (between C2 \& C3). 


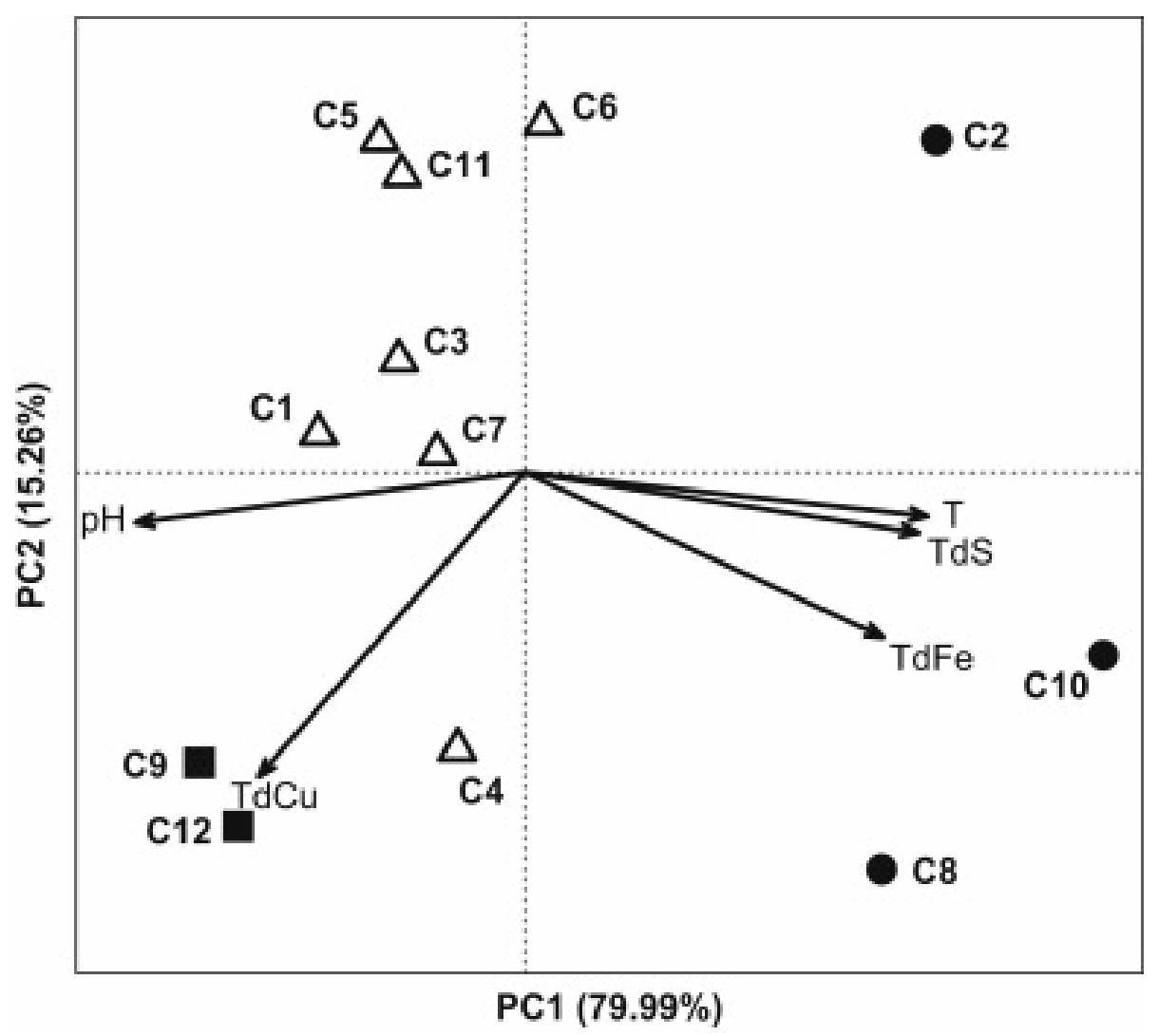

Fig. 2. First two principal axes from a PCA on mean environmental conditions at each of the 12 microhabitats (C1-C12) representing $95.25 \%$ of the total variance. Angles between environmental vectors represent linear correlations (type II scaling). Symbols assign sampling units to one of three groups obtained from k-means partitioning. All variables were standardized prior to analysis. 


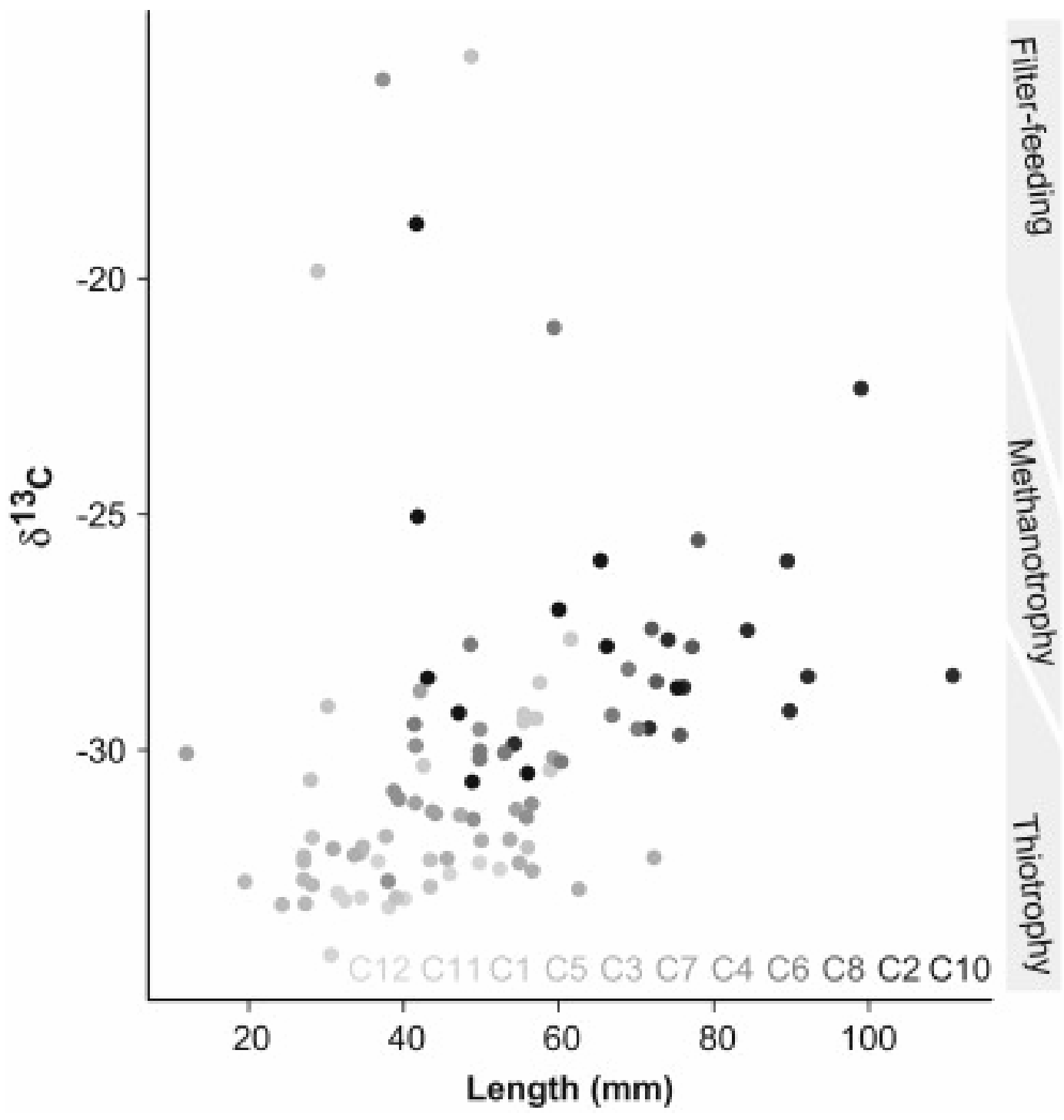

Fig. 3. Relationship between stable carbon $\left(\delta^{13} \mathrm{C}\right)$ isotope signature and length of Bathymodiolus azoricus mussels ( $n=97)$. Mussels from 11 different sampling units (C1-C12, no adult mussel on C9) are represented. Sampling units are ordered from coolest (light grey) to warmest (black). Shaded area on the right shows range of $\delta^{13} \mathrm{C}$ isotope signatures reflecting dominant feeding strategy, as suggested in the literature (Desbruyères et al. 1983, Kennicutt II et al. 1992, Pond et al. 1998, Trask and Van Dover 1999). 
(A)

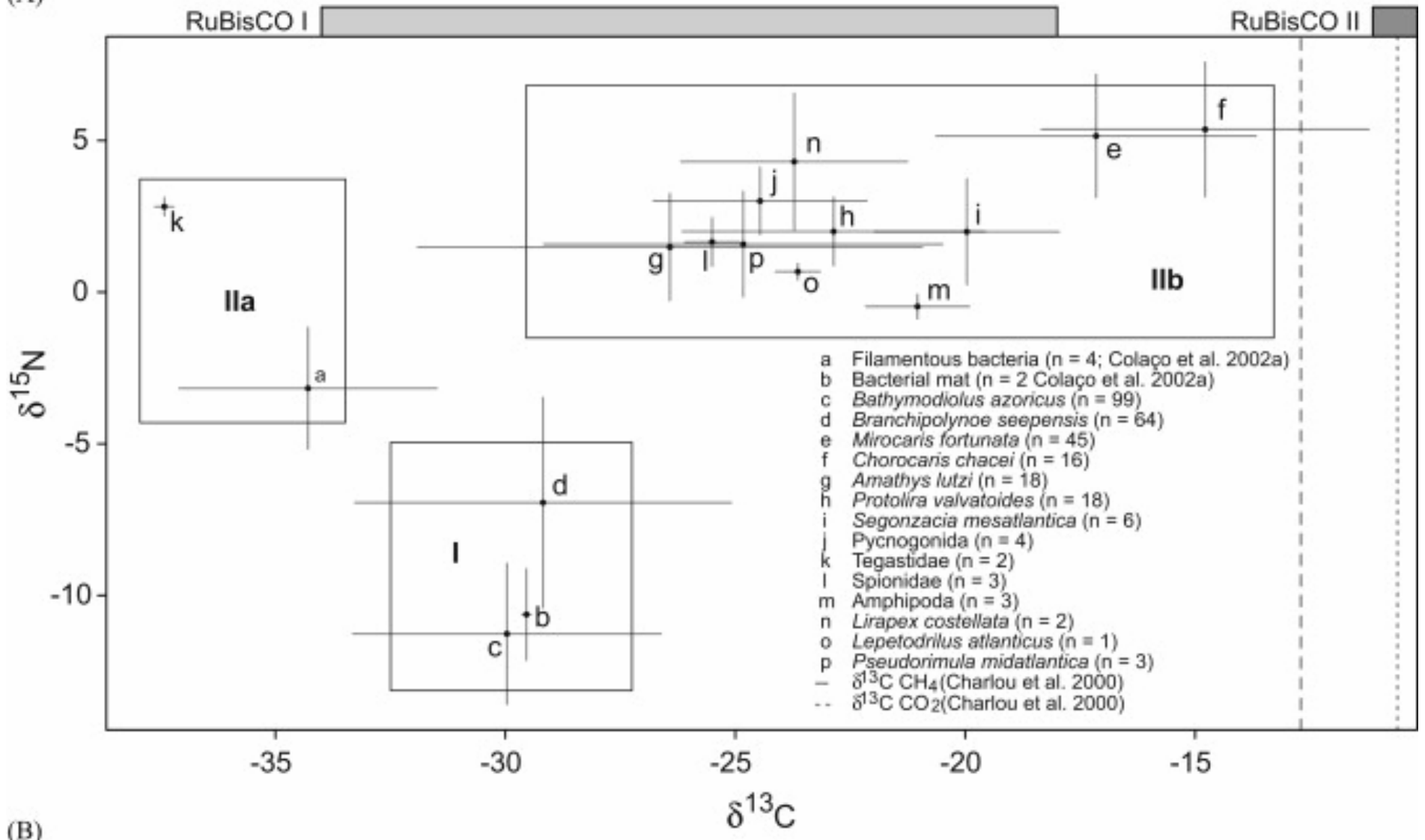

(B)

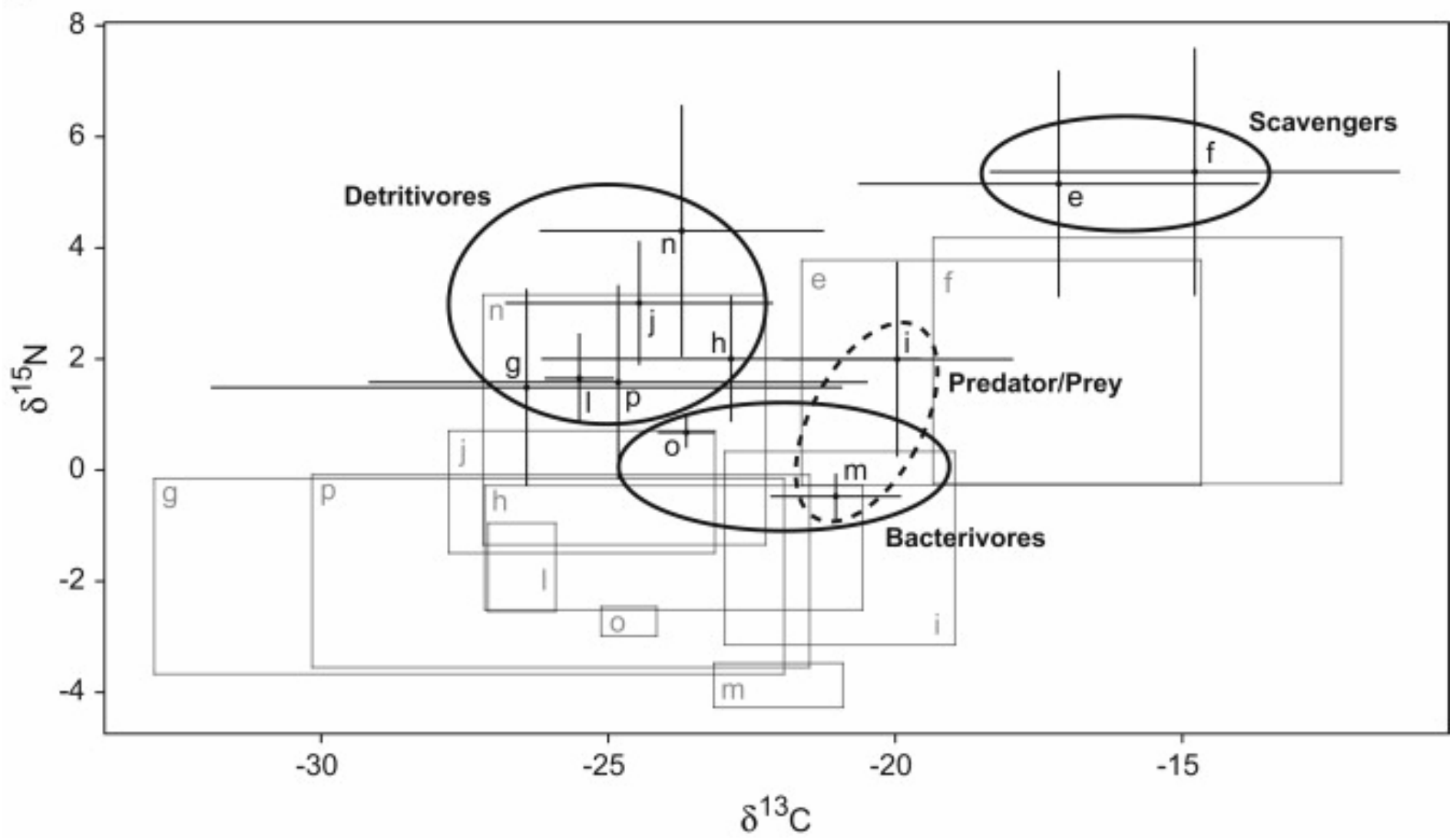

Fig. 4. Mean stable carbon $\left(\delta^{13} \mathrm{C}\right)$ and nitrogen $\left(\delta^{15} \mathrm{~N}\right)$ isotopic signatures of different taxonomic groups sampled on the Tour Eiffel hydrothermal edifice. Error bars represent standard deviation (SD). (A) Values for all sampled taxa along with two values from the 
literature representing potential food sources (data from Colaço et al. 2002). Boxes indicate trophic groups (I, Ila and IIb) as discussed in the text. Dashed vertical lines are values for $\delta^{13} \mathrm{C}$ of $\mathrm{CO}_{2}$ and $\mathrm{CH}_{4}$ collected from the Tour Eiffel hydrothermal fluids (Charlou et al. 2000). Range of isotopic values indicative of RuBisCO I or II activity are represented by filled boxes. (B) Close-up of the free-living microbe trophic group. Grey boxes represent range of isotopic values for potential food sources. They were obtained by applying a shift of $-1 \%{ }^{13} \mathrm{C}$ and of $3.4 \% \circ \delta^{15} \mathrm{~N}$ to the mean $\pm 1 \mathrm{SD}$ for each taxon. Letters in grey identify corresponding consumers.

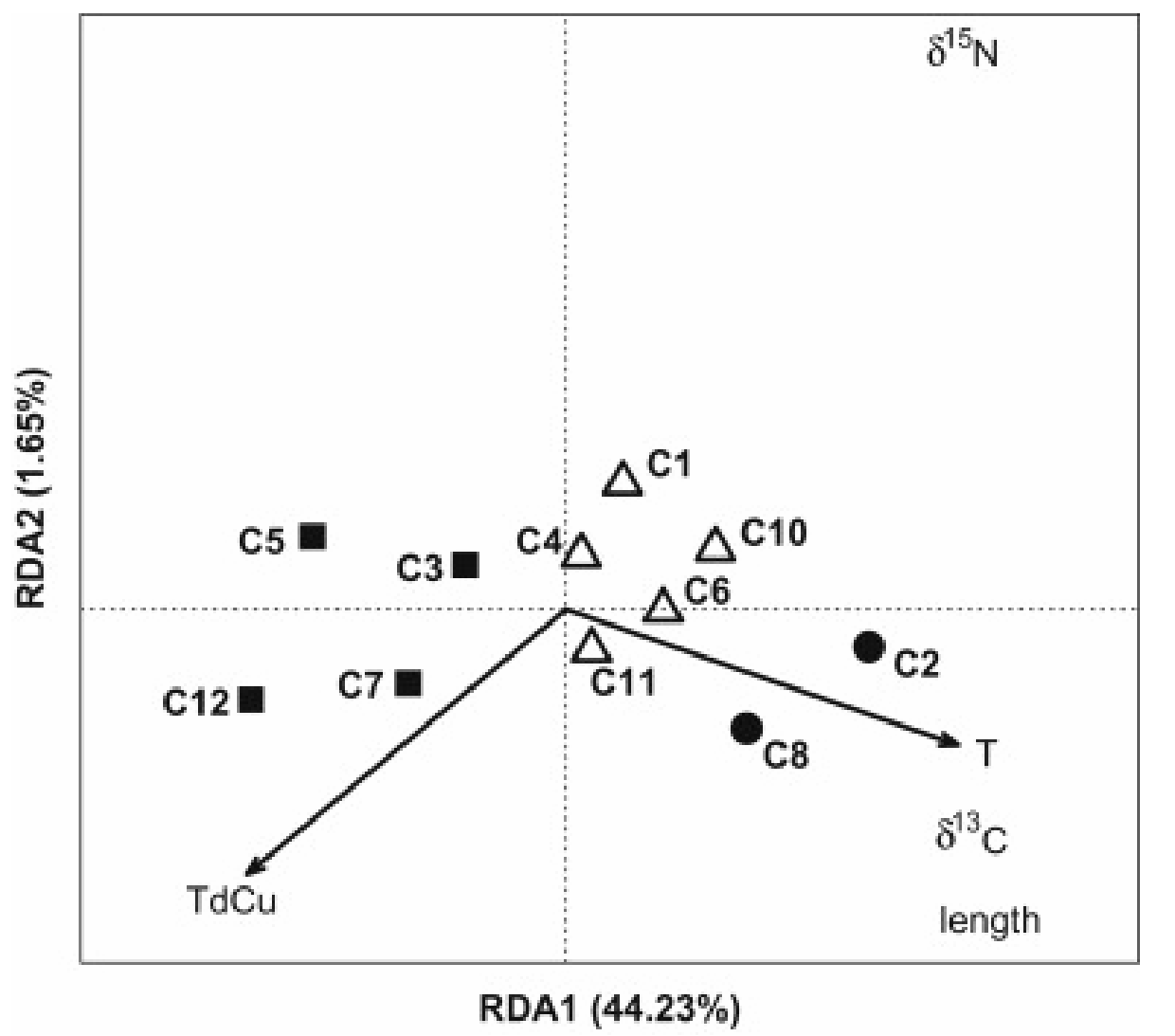

Fig. 5. The two canonical axes of a RDA on mean length and carbon and nitrogen isotope signatures of Bathymodiolus azoricus mussels from 11 microhabitats (C1-C12, no adult mussel on C9), as a function of mean temperature ( $T$ ) and total dissolved copper concentration $(\mathrm{TdCu})$. The two canonical axes explain $45.88 \%$ of the total variance. Distances between microhabitats represent their resemblance (type I scaling). Symbols assign microhabitats to one of three groups obtained from k-means partitioning on isotope signatures and length. All variables were standardized prior to analyses. 

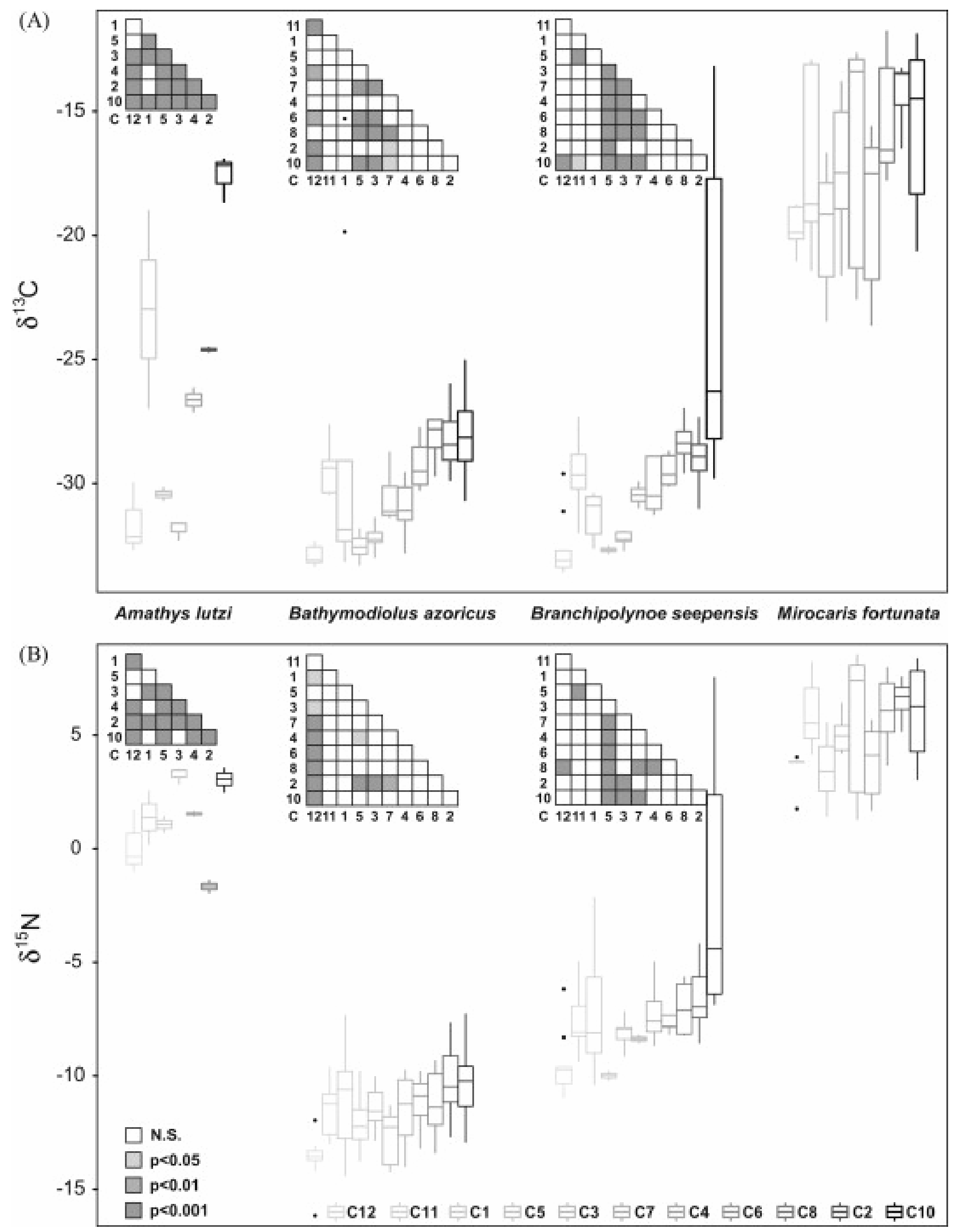

Fig. 6. Among-microhabitat variability of $(A)$ stable carbon $\left(\delta^{13} C\right)$ and $(B)$ nitrogen $\left(\delta^{15} N\right)$ isotope signatures of four selected species that colonize Bathymodiolus azoricus mussel assemblages on the Tour Eiffel hydrothermal edifice. Microhabitats (C1-C12) are ordered by increasing average temperature. Boxes contain $50 \%$ of observations with horizontal bars 
representing median, and vertical bars most extreme non-outlier values. Outliers are represented by black dots.

\section{Tables}

Table 1. Mean environmental conditions in each of the 12 sampled microhabitats. Standard deviations are given in parentheses. TdS: total dissolved sulfide, TdFe: total dissolved iron, $\mathrm{TdCu}$ : total dissolved copper. Lower panel gives the value of the Kendall rank correlations between environmental variables and their associated uncorrected $p$ values (N.S.: not significant; *: $p<0.05$; **: $p<0.01$; ${ }^{* \star *}: p<0.001$ ).

\begin{tabular}{lccccc}
\hline \hline Location & $\mathbf{T}\left({ }^{\circ} \mathbf{C}\right)$ & $\mathbf{p H}$ & TdS $(\mu \mathrm{mol} / \mathrm{L})$ & $\begin{array}{c}\text { TdFe } \\
(\mu \mathrm{mol} / \mathrm{L})\end{array}$ & $\begin{array}{c}\text { TdCu } \\
(\mu \mathrm{mol} / \mathrm{L})\end{array}$ \\
\hline \hline C1 & $4.91(0.47)$ & $6.94(0.18)$ & $1.31(0.78)$ & $0.36(0.44)$ & $1.56(0.87)$ \\
C2 & $7.63(1.27)$ & $5.90(0.16)$ & $34.37(5.24)$ & $1.79(0.60)$ & $0.08(0.06)$ \\
C3 & $5.35(0.50)$ & $6.72(0.20)$ & $3.36(1.76)$ & $0.36(0.19)$ & $1.36(0.21)$ \\
C4 & $5.67(0.50)$ & $6.61(0.09)$ & $6.07(4.37)$ & $1.69(0.77)$ & $2.06(1.29)$ \\
C5 & $5.11(0.48)$ & $6.87(0.10)$ & $1.85(0.87)$ & $0.14(0.20)$ & $0.80(0.42)$ \\
C6 & $6.04(0.42)$ & $6.43(0.04)$ & $7.51(2.94)$ & $0.39(0.25)$ & $0.67(0.43)$ \\
C7 & $5.55(0.28)$ & $6.55(0.04)$ & $6.35(2.83)$ & $0.41(0.12)$ & $1.60(0.06)$ \\
C8 & $7.49(1.54)$ & $6.02(0.38)$ & $33.41(10.41)$ & $3.53(2.67)$ & $1.62(1.96)$ \\
C9 & $4.79(0.12)$ & $7.34(0.13)$ & $1.46(0.44)$ & $0.30(0.18)$ & $2.38(1.37)$ \\
C10 & $8.79(2.71)$ & $5.99(0.38)$ & $34.94(21.94)$ & $5.25(3.60)$ & $0.46(0.65)$ \\
C11 & $4.85(0.26)$ & $6.72(0.31)$ & $2.29(1.20)$ & $0.50(0.37)$ & $0.86(0.37)$ \\
C12 & $4.81(0.34)$ & $7.06(0.56)$ & $2.33(1.06)$ & $0.40(0.44)$ & $2.60(2.21)$ \\
\hline pH & $-0.88^{* \star *}$ & - & - & - & - \\
TdS & $0.79^{* \star}$ & $-0.85^{* \star *}$ & - & - & - \\
TdFe & $0.55^{*}$ & $-0.55^{*}$ & $0.58^{* *}$ & - & - \\
TdCu & $-0.39^{*}$ & $0.45^{*}$ & $-0.30^{\text {N.S. }}$ & $-0.12^{\text {N.S }}$ & - \\
\hline \hline
\end{tabular}


Table 2. Isotopic signatures $\left(\delta^{13} \mathrm{C}\right.$ and $\left.\delta^{15} \mathrm{~N}\right)$ for the most abundant mega- and macrofaunal taxa found in each microhabitat (location) sampled on the Tour Eiffel hydrothermal edifice. Standard deviations are given in parentheses. n: number of sample analyzed, F: frozen specimen, A: preserved in formalin/alcohol. B. azoricus values are mean for an equal number of gills and feet except for locations with an uneven sample size (C1: 5 gills, 4 feet; C7: 3 gills and 4 feet; C8: 3 gills and 2 feet).

\begin{tabular}{|c|c|c|c|c|c|c|}
\hline Location & Taxonomic group & $\delta^{13} \mathrm{C}$ & $\delta^{15} \mathrm{~N}$ & $\overline{\mathrm{n}}$ & Relative abundance & Preservatio \\
\hline \multirow{8}{*}{$\mathrm{C} 1$} & "Bathymodiolus azoricus & $-28.57(6.5)$ & $-10.08(4.2)$ & 9 & 26.79 & $\bar{F}$ \\
\hline & Branchipolynoe seepensis int. & $-27.66(5.1)$ & $-5.34(3.3)$ & 3 & \multirow{2}{*}{12.53} & $\mathrm{~F}$ \\
\hline & Branchipolynoe seepensis & $-31.98(0.9)$ & $-8.98(1.5)$ & 3 & & $\mathrm{~F}$ \\
\hline & Mirocaris fortunata & $-17.13(3.9)$ & $5.97(1.7)$ & 5 & 1.58 & $\mathrm{~F}$ \\
\hline & Amathys lutzi & $-22.97(5.6)$ & $1.37(1.7)$ & 2 & 9.69 & A \\
\hline & Protolira valvatoides & $-25.13(0.3)$ & $1.31(0.5)$ & 5 & 6.46 & $F \& A$ \\
\hline & Segonzacia mesatlantica & -23.24 & 0.44 & 1 & 1 & $\mathrm{~F}$ \\
\hline & Lepetodrilus atlanticus & -23.64 & 0.68 & 1 & 3.47 & A \\
\hline \multirow{7}{*}{$\mathrm{C} 2$} & Bathymodiolus azoricus & $-27.75(2.2)$ & $-9.92(2.1)$ & 10 & 9.58 & $\mathrm{~F}$ \\
\hline & Branchipolynoe seepensis int. & $-26.57(6.1)$ & $-4.72(4.8)$ & 5 & \multirow{2}{*}{1.60} & $\mathrm{~F}$ \\
\hline & Branchipolynoe seepensis & $-29.06(0.3)$ & $-7.10(1.0)$ & 3 & & $\mathrm{~F}$ \\
\hline & Mirocaris fortunata & $-14.29(1.4)$ & $6.53(0.9)$ & 5 & 12.14 & $\mathrm{~F}$ \\
\hline & Chorocaris chacei & $-14.52(1.7)$ & $5.69(1.2)$ & 5 & 3.35 & $\mathrm{~F}$ \\
\hline & Amathys lutzi & $-24.60(0.1)$ & $-1.67(0.4)$ & 2 & 5.91 & $A$ \\
\hline & Segonzacia mesatlantica & -20.52 & 1.50 & 1 & 0.80 & $\mathrm{~F}$ \\
\hline \multirow{10}{*}{ C3 } & Bathymodiolus azoricus & $-32.20(0.4)$ & $-11.44(0.9)$ & 10 & 1.22 & $\mathrm{~F}$ \\
\hline & Branchipolynoe seepensis int. & $-32.30(0.3)$ & $-7.85(0.5)$ & 4 & \multirow{2}{*}{0.27} & $\mathrm{~F}$ \\
\hline & Branchipolynoe seepensis & -31.96 & -9.12 & 1 & & $\mathrm{~F}$ \\
\hline & Mirocaris fortunate & $-19.77(2.8)$ & $3.48(1.6)$ & 5 & 0.27 & $\mathrm{~F}$ \\
\hline & Chorocaris chacei & -26.86 & -2.13 & 1 & 0.01 & $\mathrm{~F}$ \\
\hline & Amathys lutzi & $-31.81(0.4)$ & $3.27(0.4)$ & 3 & 5.54 & A \\
\hline & Protolira valvatoides & -26.79 & 2.31 & 1 & 0.11 & $A$ \\
\hline & Segonzacia mesatlantica & -19.45 & 2.16 & 1 & 0.01 & $\mathrm{~F}$ \\
\hline & Pycnogonida & -27.92 & 2.04 & 1 & 0.06 & $\mathrm{~F}$ \\
\hline & Tegastidae & $-37.42(0.2)$ & $2.82(0.3)$ & 2 & 83.79 & A \\
\hline \multirow{5}{*}{$\mathrm{C} 4$} & Bathymodiolus azoricus & $-29.61(5.0)$ & $-10.78(3.1)$ & 10 & 10.46 & $\mathrm{~F}$ \\
\hline & Branchipolynoe seepensis int. & $-29.45(2.6)$ & $-7.21(1.6)$ & 4 & 1.75 & $\mathrm{~F}$ \\
\hline & Mirocaris fortunata & $-16.57(4.9)$ & $5.56(3.4)$ & 5 & 0.79 & $\mathrm{~F}$ \\
\hline & Amathys lutzi & $-26.63(0.7)$ & $1.54(0.2)$ & 2 & 8.93 & $A$ \\
\hline & Protolira valvatoides & -26.07 & 1.41 & 1 & 0.90 & $A$ \\
\hline \multirow{7}{*}{$\mathrm{C} 5$} & Bathymodiolus azoricus & $-32.56(0.5)$ & $-12.11(1.2)$ & 10 & 8.85 & $\mathrm{~F}$ \\
\hline & Branchipolynoe seepensis int. & $-32.66(0.2)$ & $-9.99(0.3)$ & 2 & 0.71 & $\mathrm{~F}$ \\
\hline & Amathys lutzi & $-30.42(0.4)$ & $1.07(0.5)$ & 2 & 6.41 & $A$ \\
\hline & Protolira valvatoides & $-25.71(0.5)$ & $0.02(0.1)$ & 2 & 0.80 & $A$ \\
\hline & Spionidae & -25.92 & 2.21 & 1 & 0.16 & $A$ \\
\hline & Amphipoda & -21.42 & -0.08 & 1 & 0.85 & $A$ \\
\hline & Lirapex costellata & -25.46 & 2.71 & 1 & 0.14 & $A$ \\
\hline \multirow{6}{*}{ C6 } & Bathymodiolus azoricus & $-28.59(2.8)$ & $-10.78(1.8)$ & 10 & 6.24 & $\mathrm{~F}$ \\
\hline & Branchipolynoe seepensis & $-29.47(0.7)$ & $-7.88(0.4)$ & 5 & 2.15 & $\mathrm{~F}$ \\
\hline & Mirocaris fortunate & $-19.00(3.5)$ & $3.81(1.7)$ & 5 & 10.44 & $\mathrm{~F}$ \\
\hline & Chorocaris chacei & -13.29 & 6.78 & 1 & 0.10 & $\mathrm{~F}$ \\
\hline & Segonzacia mesatlantica & -20.67 & -0.08 & 1 & 0.31 & $\mathrm{~F}$ \\
\hline & Amphipoda & -21.92 & -0.88 & 1 & 6.76 & A \\
\hline \multirow{3}{*}{$\mathrm{C} 7$} & Bathymodiolus azoricus & $-30.57(1.0)$ & $-12.76(1.3)$ & 7 & 6.09 & $\mathrm{~F}$ \\
\hline & Branchipolynoe seepensis int. & $-30.36(0.9)$ & $-8.42(0.2)$ & 2 & 1.02 & $\mathrm{~F}$ \\
\hline & Mirocaris fortunata & $-17.37(3.1)$ & $5.07(0.9)$ & 5 & 55.33 & $\mathrm{~F}$ \\
\hline \multirow{5}{*}{$\mathrm{C} 8$} & Bathymodiolus azoricus & $-27.80(1.5)$ & $-11.24(1.6)$ & 5 & 4.38 & $\mathrm{~F}$ \\
\hline & Branchipolynoe seepensis int. & $-28.32(1.1)$ & $-7.03(1.4)$ & 4 & 2.19 & $\mathrm{~F}$ \\
\hline & Mirocaris fortunata & $-14.86(2.6)$ & $6.53(1.3)$ & 5 & 54.74 & $\mathrm{~F}$ \\
\hline & Chorocaris chacei & $-14.64(1.5)$ & $5.54(1.1)$ & 5 & 16.79 & $\mathrm{~F}$ \\
\hline & Segonzacia mesatlantica & -17.56 & 3.62 & 1 & 2.19 & $\mathrm{~F}$ \\
\hline \multirow{3}{*}{ C9 } & Protolira valvatoides & -19.85 & 4.39 & 1 & 18.41 & $A$ \\
\hline & Pycnogonida & -23.15 & 3.99 & 1 & 1.08 & $A$ \\
\hline & Lirapex costellata & -21.98 & 5.90 & 1 & 7.58 & A \\
\hline \multirow{7}{*}{ C10 } & Bathymodiolus azoricus & $-28.06(1.8)$ & $-10.05(2.1)$ & 10 & 14.33 & $\mathrm{~F}$ \\
\hline & Branchipolynoe seepensis int. & $-28.08(1.4)$ & $-6.10(1.0)$ & 5 & \multirow{2}{*}{7.32} & $\mathrm{~F}$ \\
\hline & Branchipolynoe seepensis & $-18.69(5.5)$ & $2.57(5.0)$ & 4 & & $\mathrm{~F}$ \\
\hline & Mirocaris fortunata & $-15.65(3.7)$ & $5.96(2.3)$ & 5 & 10.51 & $\mathrm{~F}$ \\
\hline & Chorocaris chacei & $-12.65(0.9)$ & $6.29(0.7)$ & 5 & 0.16 & $\mathrm{~F}$ \\
\hline & Amathys lutzi & $-17.59(0.9)$ & $3.04(0.5)$ & 3 & 3.82 & $A$ \\
\hline & Amphipoda & -19.77 & -0.46 & 1 & 1.91 & $A$ \\
\hline
\end{tabular}




\begin{tabular}{|c|c|c|c|c|c|c|}
\hline \multirow{9}{*}{ C11 } & Bathymodiolus azoricus & $-29.82(1.8)$ & $-11.48(1.2)$ & 8 & 18.84 & $\mathrm{~F}$ \\
\hline & Branchipolynoe seepensis int. & $-29.22(1.1)$ & $-7.55(1.7)$ & 5 & \multirow{2}{*}{5.32} & $\mathrm{~F}$ \\
\hline & Branchipolynoe seepensis & $-29.74(1.8)$ & $-7.78(1.0)$ & 5 & & $\mathrm{~F}$ \\
\hline & Mirocaris fortunata & $-19.74(0.9)$ & $3.45(1.0)$ & 5 & 2.31 & $\mathrm{~F}$ \\
\hline & Amathys lutzi & -23.34 & 2.90 & 1 & 6.71 & A \\
\hline & Protolira valvatoides & $-19.74(2.5)$ & $2.71(0.2)$ & 7 & 9.71 & $F \& A$ \\
\hline & Segonzacia mesatlantica & -18.35 & 4.33 & 1 & 0.58 & $\mathrm{~F}$ \\
\hline & Pycnogonida & -23.18 & 3.93 & 1 & 0.35 & $\mathrm{~F}$ \\
\hline & Pseudorimula midatlantica & $-22.33(0.4)$ & $2.58(0.1)$ & 2 & 1.73 & $F \& A$ \\
\hline \multirow{8}{*}{$\mathrm{C} 12$} & Bathymodiolus azoricus & $-33.01(0.6)$ & $-13.66(1.1)$ & 10 & 26.23 & $\mathrm{~F}$ \\
\hline & Branchipolynoe seepensis int. & $-33.17(0.36)$ & $-10.36(0.5)$ & 4 & \multirow{2}{*}{8.00} & $\mathrm{~F}$ \\
\hline & Branchipolynoe seepensis & $-32.04(1.8)$ & $-8.80(1.6)$ & 5 & & $\mathrm{~F}$ \\
\hline & Amathys lutzi & $-31.59(1.4)$ & $0.11(1.4)$ & 3 & 35.78 & A \\
\hline & Protolira valvatoides & -23.50 & 2.40 & 1 & 0.87 & $A$ \\
\hline & Pycnogonida & -23.59 & 2.07 & 1 & 0.19 & $A$ \\
\hline & Spionidae & -25.09 & 1.09 & 1 & 0.39 & $A$ \\
\hline & Pseudorimula midatlantica & -29.82 & -0.42 & 1 & 0.58 & A \\
\hline
\end{tabular}


Table 3. Effect of alcohol preservation compared to the effect of freezing on $\delta^{13} \mathrm{C}$ and $\delta^{15} \mathrm{~N}$ signatures for three taxonomic groups sampled on the Tour Eiffel hydrothermal edifice. The numbers in bold show outlier values. The difference between the mean observed isotopic ratio for both methods is given as a measure of disagreement between the two (Diff.= Frozen - Alcohol).

\begin{tabular}{|c|c|c|c|c|c|c|c|c|}
\hline Taxonomic group & Location & $\begin{array}{c}\text { Preservatio } \\
\mathbf{n}\end{array}$ & $\delta^{13} \mathrm{C}$ & Mean $\delta^{13} \mathrm{C}$ & Diff. & $\begin{array}{c}\delta^{15} \\
\mathrm{~N} \\
\end{array}$ & Mean $\delta^{15} \mathrm{~N}$ & Diff. \\
\hline \multirow{5}{*}{ Protolira valvatoides } & $\mathrm{C} 1$ & Frozen & $\begin{array}{c}- \\
25.28\end{array}$ & -25.24 & -0.17 & 1.01 & 1.28 & -0.05 \\
\hline & $\mathrm{C} 1$ & Frozen & 25.19 & & & 1.55 & \multirow{4}{*}{1.33} & \\
\hline & $\mathrm{C} 1$ & Alcohol & $\stackrel{-}{-} 25.03$ & -25.07 & & 1.63 & & \\
\hline & $\mathrm{C} 1$ & Alcohol & 24.72 & & & 1.74 & & \\
\hline & $\mathrm{C} 1$ & Alcohol & $\begin{array}{c}- \\
25.44 \\
\end{array}$ & & & 0.62 & & \\
\hline \multirow{7}{*}{ Protolira valvatoides } & C11 & Frozen & 19.62 & -18.13 & 2.82 & 2.38 & \multirow{7}{*}{$\begin{array}{l}3 \\
\\
\\
\\
\\
\end{array}$} & -0.24 \\
\hline & C11 & Frozen & 20.46 & & & 2.51 & & \\
\hline & C11 & Frozen & 14.33 & & & 2.83 & & \\
\hline & C11 & Alcohol & 21.04 & -20.95 & & 2.80 & & \\
\hline & C11 & Alcohol & 19.67 & & & 2.62 & & \\
\hline & C11 & Alcohol & 21.86 & & & 2.70 & & \\
\hline & C11 & Alcohol & 21.22 & & & 3.11 & & \\
\hline \multirow{2}{*}{$\begin{array}{l}\text { Pseudorimula } \\
\text { mesatlantica }\end{array}$} & C11 & Frozen & 22.05 & & \multirow[t]{2}{*}{0.56} & 2.49 & & -0.19 \\
\hline & C11 & Alcohol & 22.61 & & & 2.68 & & \\
\hline \multirow{4}{*}{ Pycnogonida } & C11 & Frozen & 23.18 & -25.55 & \multirow[t]{4}{*}{-2.18} & 3.93 & \multirow[t]{2}{*}{2.98} & \multirow[t]{4}{*}{-0.05} \\
\hline & C3 & Frozen & 27.92 & & & 2.04 & & \\
\hline & $\mathrm{C} 12$ & Alcohol & 23.59 & -23.37 & & 2.07 & \multirow[t]{2}{*}{3.03} & \\
\hline & C9 & Alcohol & $\begin{array}{c}- \\
23.15 \\
\end{array}$ & & & 3.99 & & \\
\hline
\end{tabular}


Table 4. Kendall rank correlations between temperature and isotopic signature $\left(\delta^{13} \mathrm{C}\right.$ and $\delta^{15} \mathrm{~N}$ ) for seven species. T: Coefficient of correlation, $z$ : normal approximation, $p$ : probabilities after Holm correction; the uncorrected probabilities are presented in parentheses. $T$ range gives the minimum and maximum temperature values in sampled locations. Bold indicates significant correlations and italic negative correlations. N.S.: not significant; *: $p<0.05$; **: $p<0.01 ; * \star *$ : $p<0.001$.

\begin{tabular}{|c|c|c|c|c|c|c|c|c|c|}
\hline \multirow[t]{2}{*}{ Species } & \multirow[t]{2}{*}{$\mathrm{n}_{\text {ind }}$} & \multirow{2}{*}{$\begin{array}{c}\mathrm{n}_{\text {locatio }} \\
\text { ns }\end{array}$} & \multicolumn{3}{|c|}{$\delta^{13} \mathrm{C}$} & \multicolumn{3}{|c|}{${ }_{15}^{\delta} \mathrm{N}$} & \multirow{2}{*}{$\begin{array}{c}\text { T range } \\
\left({ }^{\circ} \mathrm{C}\right)\end{array}$} \\
\hline & & & $\tau$ & $z$ & $p$ & $\tau$ & $z$ & $p$ & \\
\hline $\begin{array}{c}\text { Bathymodiolus } \\
\text { azoricus }\end{array}$ & 99 & 11 & $0.51^{\star \star \star}$ & 7.18 & $\begin{array}{l}<0.001 \\
(<0.001)\end{array}$ & $0.31^{\star \star \star}$ & 4.40 & $\begin{array}{c}0.001 \\
(<0.001)\end{array}$ & $\begin{array}{l}4.81- \\
8.79\end{array}$ \\
\hline $\begin{array}{c}\text { Branchipolynoe } \\
\text { seepensis }\end{array}$ & 64 & 11 & $0.49^{\star \star \star}$ & 5.48 & $\begin{array}{l}<0.001 \\
(<0.001)\end{array}$ & $0.47^{\star \star \star}$ & 5.24 & $\begin{array}{l}<0.001 \\
(<0.001)\end{array}$ & $\begin{array}{l}4.81- \\
8.79\end{array}$ \\
\hline Mirocaris fortunata & 46 & 9 & $0.30^{*}$ & 2.82 & $\begin{array}{c}0.038 \\
(<0.005)\end{array}$ & $0.26^{\text {N.S. }}$ & 2.50 & $\begin{array}{l}0.080 \\
(0.012)\end{array}$ & $\begin{array}{l}4.85- \\
8.79\end{array}$ \\
\hline Protolira valvatoides & 18 & 7 & $0 . \overline{7} 1^{* \star}$ & $\begin{array}{c}- \\
3.85\end{array}$ & $\begin{array}{c}0.001 \\
(<0.001)\end{array}$ & $-0.64^{* *}$ & 3.45 & $\begin{array}{c}0.006 \\
(<0.001)\end{array}$ & $\begin{array}{l}4.79- \\
5.67\end{array}$ \\
\hline $\begin{array}{c}\text { Segonzacia } \\
\text { mesatlantica }\end{array}$ & 6 & 6 & $\underset{\mathrm{S}}{0.07^{\mathrm{N}}}$ & 8 & $\begin{array}{l}1.000 \\
(1.000)\end{array}$ & $0.20^{\text {N.S. }}$ & 6 & $\begin{array}{c}1.0000 \\
(0.719)\end{array}$ & $\begin{array}{c}4.85- \\
7.63\end{array}$ \\
\hline Amathys lutzi & 18 & 8 & $0.45^{\mathrm{N} .}$ & 2.53 & $\begin{array}{l}0.080 \\
(0.012)\end{array}$ & $0.20^{\text {N.S. }}$ & 1.15 & $\begin{array}{l}0.752 \\
(0.251)\end{array}$ & $\begin{array}{c}4.81- \\
8.79\end{array}$ \\
\hline Chorocaris chacei & 16 & 5 & $0.43^{N}$ & 2.16 & $\begin{array}{l}0.152 \\
(0.030)\end{array}$ & $0.30^{\text {N.S. }}$ & 1.51 & $\begin{array}{l}0.527 \\
(0.132) \\
\end{array}$ & $\begin{array}{l}5.35- \\
8.79 \\
\end{array}$ \\
\hline All species & 285 & 12 & $0.28^{\star \star \star *}$ & 6.76 & $\begin{array}{l}<0.001 \\
(<0.001)\end{array}$ & $0.14^{\star *}$ & 3.31 & $\begin{array}{c}0.008 \\
(<0.001)\end{array}$ & $\begin{array}{l}4.79- \\
8.79\end{array}$ \\
\hline
\end{tabular}


Table 5. Among-microhabitat variability in isotopic signatures for four species found on the Tour Eiffel hydrothermal edifice. Results of Kruskal-Wallis test are given for both $\delta^{13} \mathrm{C}$ and $\delta^{15} \mathrm{~N}$ values. Significant differences are in bold. N.S.: not significant; *: $p<0.05 ;{ }^{\star *}: p<0.01 ; * \star *$ : $p<0.001$.

\begin{tabular}{|c|c|c|c|c|c|c|}
\hline \multirow{2}{*}{ Species } & \multirow{2}{*}{$\mathrm{n}_{\text {ind }}$} & \multirow{2}{*}{$\begin{array}{c}\mathrm{n}_{\text {locatio }} \\
\text { ns }\end{array}$} & \multicolumn{2}{|c|}{$\delta^{13} \mathrm{C}$} & \multicolumn{2}{|c|}{$\delta^{15} \mathrm{~N}$} \\
\hline & & & $\mathrm{H}$ & $p$ & $\mathrm{H}$ & $p$ \\
\hline Amathys lutzi & 17 & 7 & $14.29^{*}$ & 0.027 & $12.97^{*}$ & 0.044 \\
\hline $\begin{array}{l}\text { Bathymodiolus } \\
\text { azoricus }\end{array}$ & 99 & 11 & $64.36^{\star \star \star}$ & $<0.001$ & $32.77^{\star \star \star}$ & $<0.001$ \\
\hline $\begin{array}{l}\text { Branchipolynoe } \\
\text { seepensis }\end{array}$ & 64 & 11 & $40.81^{\star \star \star}$ & $<0.001$ & $31.16^{\star \star \star}$ & $<0.001$ \\
\hline Mirocaris fortunata & 45 & 9 & $\begin{array}{l}13.59^{N} \\
\text { s. }\end{array}$ & 0.093 & $\begin{array}{l}15.11 \\
\text { N.S. }\end{array}$ & 0.057 \\
\hline
\end{tabular}

